\title{
Kurgusal Fizyonominin Şarkî Aynaları: Batı-dışı Modernite ve Modern Türk Romanı Üzerinde Bilişsel Bir Kültüir Çözümlemesi
}

\section{Oriental Mirrors of Fictional Physiognomy: Non-Western Modernity and a Cognitive Cultural Reading of the Modern Turkish Novel}

\author{
Murat LÜLECI ${ }^{1}$ ๔]
}

'Sorumlu yazar/Corresponding author: Murat Lüleci (Dr. Öğr. Üyesi), İstanbul Aydın Üniversitesi, Eğitim Fakültesi, Türkçe Öğretmenliği Bölümü, İstanbul, Türkiye E-posta: muratluleci@aydin.edu.tr ORCID: 0000-0002-0627-274X

Başvuru/Submitted: 16.05 .2020 Revizyon Talebi/Revision Requested: 30.05.2020

Son Revizyon/Last Revision Received: 18.08.2020

Kabul/Accepted: 01.09.2020

Online Yayın/Published Online: 13.11.2020

Atıf/Citation: Luleci, Murat. "Kurgusal Fizyonominin Şarkî Aynaları: Batı-dışı Modernite ve Modern Türk Romanı Üzerinde Bilișsel Bir Kültür Çözümlemesi." Türkiyat Mecmuası-Journal of Turkology 30, 2 (2020): 607-633.

https://doi.org/10.26650/iuturkiyat.738029

\section{ÖZ}

İnsan yüzü ve bedeni eski çağlardan bu yana derin anlamların toplandığı sırlı bir levha olarak görülmüştür. Doğu'da ilm-i sima, Batı'da fizyonomi bünyesinde gerçekleştirilen araştırmalar, yirminci yüzyılın ikinci yarısından itibaren kültür çalışmalarıyla birlikte yeni bir ivme kazanır. Fizyonomi, son yıllarda insan yüzü ve bedenini kültürel kodların biriktiği simgesel bir alan olarak ele almakta, roman da karakter fizyonomisi üzerinden bu simgelerin çözümlendiği bir alana karşılık gelmektedir. Araştırmanın amacı, Batı-dışı bir modernite olarak Türk modernleşmesinin fizyonomisini ortaya koymak ve Türk romanında bilgi ve varlık sorunsallarının ele alınışını karakterlerin yüz ve beden görünümleri üzerinden çözümlemektir. Halit Ziya'nın Mai ve Siyah ile Aşk-ı Memnu romanları üzerinde Foucault'nun tarihsel a priori ve arşiv kavramları üzerinden gerçekleştirdiğimiz yakın okumalar, adı geçen romanlarda karakterlerin yüz ve beden biçimlerinin yeni bir epistemolojinin habercisi olduğunu ortaya koymuştur. Diğer yandan Peyami Safa'nın Yalnızız ve Matmazel Noraliya'nın Koltuğu adlı romanlarında Daryush Shayegan'ın ontolojik kopuş kavramı üzerinden gerçekleştirdiğimiz yakın okumalar, Safa'nın varlık sorunsalını ele alırken, kurguladığı karakterlerin yüz ve bedenlerini kültürel birer simge alanı olarak tasarladığını göstermiştir. Sözü edilen yakın okumalar sayesinde anlaşılmıştır ki Türk Modernleşmesinin Batı-dışı bir epistemoloji ve ontolojiden kaynaklandığını ve yine kendine has bir bilgi ve varlık çizgisinde ilerlediğini ortaya koyabilmek için, karakter fizyonomisinin incelenmesi büyük önem taşımaktadır.

Anahtar kelimeler: Batı-dışı modernite, roman, fizyonomi, kültür eleştirisi, Halit Ziya Uşaklıgil, Peyami Safa, epistemoloji, ontoloji

\section{ABSTRACT}

The human face and the body have long been considered as enigmatic plates in which deep shades of meaning occur. Studies within IIIm-i Sima in the East and physiognomy in the West gained momentum with the emergence of cultural studies in the second half of the twentieth century. Physiognomy examines the human face and the body as symbolic spaces of cultural signs. The novel, on the other hand, manifests a space where these physiognomies are being displayed. The objective of this study is to reveal the physiognomy 
of Turkish modernization as a Non-western modernity and to analyze the handling of knowledge (epistemology) and being (ontology) in the modern Turkish novel through the physiognomy of fictional characters. A close reading of Halit Ziya's novels through Foucault's notions of historical a priori and archive revealed that the characters' faces bodies can be interpreted as the precursors of a new epistemology. CloseC readings of Peyami Safa's novels Yalnızız and Matmazel Noraliya'nın Koltuğu through Daryush Shayegan's notion of ontological displacement showed that Safa designed the faces and bodies of his characters as cultural symbols as well as the representation of his philosophical ideals. The selected texts Mai ve Siyah and Aşk-ı Memnu by Halit Ziya Uşaklıgil as well as Yalnızız and Matmazel Noraliya'nın Koltuğu by Peyami Safa will be examined through the lense of the physiognomy of characters in terms of their relation to the peculiarity of Turkish modernization as non-Western modernity.

Keywords: Non-Western modernity, novel, physiognomy, cultural studies, Halit Ziya Uşaklıgil, Peyami Safa, epistemology, ontology

\section{EXTENDED ABSTRACT}

The meaning of the human face and the body has been a subject of curiosity since ancient times. The Western tradition of physiognomy and phrenology as well as the Eastern tradition of ilm-i sima (knowledge of the face), ilm-i firaset (knowledge of foresight) and ilm-i kryafet (knowledge of the apparel) establish a connection between the face and body of the human and his inner world and character. Although these fields are generally accepted as pseudo-science, recent studies have revealed that the human face and body are closely related to culture and literature. The works of Johan K. Lavater deeply affected the $19^{\text {th }}$ century Western novel, and Halit Ziya Uşaklıgil, the first important representative of the modern Turkish novel, wrote his book ilm-i sima influenced by Lavater. However, a cultural analysis of character physiognomy in the context of Turkish modernization has not been carried out. Thus, this study will treat character physiognomy as a cultural symbol and perform an epistemological and ontological analysis on the modern Turkish novel.

Turkish modernization, similar to other modernities that have developed outside the West, was previously established as a non-Western modernity. The unique structure of Turkish modernization has been reflected in the physiognomy of the Turkish novel. Thus, the face and body forms of fictional characters have been realized in an epistemological and ontological system that is different from the West. Our recentr close readings showed that Michel Foucault's notions of historical a priori and archive provide a relevant framework in the analysis of Halit Ziya's novels and revealed how his texts can be interpreted as plates of deep cultural meanings in terms of non-Western modernity. Foucault puts historical a priori as a condition of reality for statements. He is in pursuit of "the conditions of emergence of statements, the law of their co-existence with others, the specific form of their mode of being, the principles according to which they survive, become transformed, and disappear". Similarly, in Foucault's words, "the archive is not that which, despite its immediate escape, safeguards the event of the statement, and preserves, for future memories, its status as an escapee; it is that which, at the very root of the statement-event, and in that which embodies it, defines at the outset the system of its enunciability". 
When viewed through Foucault's notions of historical a priori and archive, it has been observed that the physiognomy of Halit Ziya's characters reflect a change evolving from an absolute discourse to a modern one in the Western sense. In Intibah, which is the representative of the Tanzimat novel, Ali Bey's sight or way of looking is based on edeb (decency)/shyness, whereas in Aşk-ı Memnu, the state of vision/looking between Behlül and Bihter is shaped through the concepts of sin, guilt and degradation. Thus, character physiognomy, reflected as sight or smile, is in fact, not a simple description of a fictional scene, but an expression of a changing mindset.

Peyami Safa, on the other hand, is a novelist known for his ability to describe his characters in their psychological depth and also for his investigations into some of the most central philosophical questions such as being, time, knowledge and reality. Our close readings not only showed that Safa was one of the Turkish novelists with the highest knowledge of physiognomy, but also showed that he was making the most of character physiognomy when constructing his philosophical approaches. The most striking example of this is the moment when people are told, in Yalnuzız, that they will only be taken to the ideal country Simeranya with a physiognomy and a manners test. Thus, physiognomy ceases to be a simple facial and bodily appearance and becomes a symbolic domain of the novelist's modern mysticism. 


\section{Giriş}

Kişiliğimiz ile bedenimiz birbirine o kadar bă̆lıdır ki aynı talihsizliği paylaşırlar.

Marcel Proust

Bir gün insan vücudunun romanında kim bilir ne hayret verici maceralar okuyacağız!

Peyami Safa

İnsanın yüz ve beden biçimlerinin taşıdığı anlam(lar)ın ve bu anlamlara dair geliştirilen yorumların tarihi klasik antikiteye, eski Mısır, Mezopotomya, Çin ve Yunan uygarlıklarına kadar uzanır. Aristoteles, Physiognomica'sında fizyonomiyi “bedenin hareketleri, renk, yüz ifadeleri, saçın uzunluğu, tenin yumuşaklığı, ses tonu, bedenin yapısı, bedenin değişik bölümleri ve bütün olarak bedenin biçiminin incelenmesi” biçiminde tanımlar ${ }^{1}$. Erzurumlu İbrahim Hakkı, bilimler tarihinde önemli bir yeri olan Mârifetnâme'sinde (1757), insanın "âlemde olan san'atlara nazar kılup eşyâda bulunan hikmetleri bil[mesinin] ve cümlenin emsâlini kendi vücudunda bul[masının]" öneminden söz eder. Ona göre "beden-i insan âlem-i asgar ve rûhı âlem-i ekberdir. Zîra ki, her ne kim âlemde halk olunmuştur, cümlenin misâli vücûd-1 insanda bulunmuştur"' 'İsviçreli fizyonomist Johan K. Lavater'in 1775 'te kaleme aldiğ 1 Physiognomische Fragmente zur Beförderung der Menschenkenntnis und Menschenliebe adlı ünlü çalışması, Goethe ve Balzac başta olmak üzere Batılı romancıları derinden etkiler³. Lavater'in fizyonomiye dair düşünceleri o kadar etkili olmuştur ki Halit Ziya Uşaklıgil İlm-i Sima adlı eserinde büyük ölçüde Lavater'in çalışmasından yola çıkmıştır. İnsan yüzü ve bedeni hem Doğu hem de Batı'da derin anlamların toplandığı sırlı birer levha olarak görülmüştür. Bu levhadaki sırların çözülmesi de insanı hem kendisini hem de içinde kendisini gerçekleştirdiği kültürün kodlarını çözmeye bir adım daha yaklaştırabilecektir.

Son yıllarda gerçekleştirilen çalışmalar yüz ve bedenin kültürel bir simge alanı olduğunu ortaya koymuştur ${ }^{4}$. Türk romanında karakterlerin yüz ve beden biçimleri Türk modernleşmesi bağlamında kapsamlı biçimde değerlendirilmemiş, metnin dünyasında karakterlerin moderniteye verdiği tepkilerin fizyonomisi incelenmemiştir. Oysa Türk modernleşmesinin Batı-dışı bir modernite olarak temellendirilmesi ve özgül yapısının ortaya konmasında karakter fizyonomisinin incelenmesi kaçınılmazdır. Friedrich Nietzsche Tragedyanın Doğuşu'nu kavramamız için “Apolloca kültürün pek sanatlı yapıtlarını, kurulduğu temelleri görünceye

1 Aristotle, Minor Works, çev. W. S. Hett. (Cambridge: Harvard University Press, 1936), 806/25.

2 İbrahim Hakkı Erzurumî, Marifetnâme (Translitere), haz. Cafer Durmuş, (İstanbul: Erkam Yayınları, 2011), 265 .

3 Ahmet Hamdi Tanpınar, XIX. asır romanında Balzac'la beraber başlayan resim tesirini görmemenin imkânsız olduğu görüşündedir. Ona göre "Balzac büyük bir portrecidir" (Tanpınar, 1988, 296). Bu etkide resim sanatı kadar fizyonomi alanındaki çalışmaların da rolü olduğu anlaşılmaktadır.

4 Bk. Graeme Tytler, Physiognomy in the European Novel: Faces and Fortunes (Princeton: Princeton University Press, 1982); Tahsin Yücel, Insanlık Güldürüsü'nde Yüzler ve Bildiriler. (İstanbul: YKY, 1997); Sibylle Baumbach, Shakespeare and the Art of Physiognomy (Penrith: Humanities Ebooks, 2008); Lisa Zunshine, "Theory of Mind and Fictions of Embodied Transparency" Narrative 16/1, (2008), 65-92. 
değin taş taş söküp kaldırmamız gerekir" der ${ }^{5}$. Bu çalışma da modern Türk romanda bilgi ve varlı problemlerinin algılanmasında meydana gelen değişimleri yüz ve beden görünümleri üzerinden anlamlandırabilmek için girişilmiş bir taş sökme işlemi olarak okunabilir.

Bu çalışmanın temel argümanı şudur: Tanzimat'ın ardından Türk kültürüne Batı'dan veri girişi artmış; bu artış, romanımızda epistemolojik ve ontolojik bir eksen kayması yaşanmasını beraberinde getirmiştir. Ahmet Hamdi Tanpınar'ın edebiyatımızın yabancı etkilerle zenginleşerek yavaş, fakat sürekli olarak hissedilir biçimde Batı'ya doğru gittiğine dair tespitinin, bu epistemolojik ve ontolojik eksen kaymasıyla bir ilgisi olduğu anlaşılmaktadır ${ }^{6}$. Bu eksen kaymasının bir sonucu olarak karakterlerin varlık konusuna dair sorduğu sorular daha katmanlı hâle gelmiş, bilgi ve varlık sorunsallarının ele alınışı karakterlerin yüz ve beden biçimleri üzerinden verilmiş; böylece karakterlerin fizyonomileri kültürün değişen kodlarının simgesel alanına dönüşmüştür. Bu nedenle Tanzimat sonrası karakter fizyonomisi üzerinden yapılacak bir yakın okuma, sanatçımızın bilgi ve varlık problemine yaklaşımındaki değişimi ortaya koyabilmek adına büyük önem taşımaktadır.

\section{Kültür Eleştirisi ve Bilişsel Kültür Çalışmaları}

Kültür, Edward B. Tylor'ın Primitive Culture'daki artık klasikleşmiş tanımında belirttiği gibi "bilgi, inanç, sanat, ahlak, hukuk, gelenek-görenek ile toplumun bir parçası olarak insanın kazandığı diğer yetileri içine alan o karmaşık bütünlüktür" " . Matthew Arnold, idealist bir kültür kuramı geliştirerek, yirminci yüzyılda beşerî bilimlerin itibar kazanmasını sağlamıştı. Antonio Gramsci kültürü bir hegemonya olarak ele alırken, Stuart Hall onu ortak anlamlardan hareketle tanımladi ${ }^{8}$. John Fiske ve Raymond Williams'ın kültürün politik ve ekonomik yanlarını vurguladığını, Michel Foucault'nun onu güç ve iktidar odaklı ele aldığını görürüz.

Bilişsel bilim(ler), felsefe, psikoloji, yapay zekâ, sinir bilim, dilbilim ve antropolojiyi içine alan, zihin ve zekânın incelendiği disiplinler arası bir çalışma alanıdır ${ }^{9}$. Bilişsel kültür eleştirisi ise bilişsel yazın bilim çalışmaları ve kültür incelemelerini bir araya getirmektedir. Bilişsel kültür eleştirmeni Lisa Zunshine, çevremizdeki kişilerin dış görüntülerinin (yüz ve beden biçimlerinin) iç dünyaları ve zihinsel durumlarını yansıttığı biçimindeki alışkanlığımıza "cisimleşen geçirgenlik" adını verir. Zunshine'a göre, “zihin okuma adaptasyonları ile yaşamlarımızın tam olarak nasıl yapılandırıldığını kavramaktan şimdilik uzak olsak da bu adaptasyonların kültürel etkisinin, en az görme yetimiz kadar derin ve kapsamlı olması mümkündür"'10. Bilişsel kültür eleştirisi Batı-dışı modernleşme deneyimlerinin çözümlenmesinde verimli bir çalışma zemini sunar. "Bilişsel yazın bilimin görevi, insani bakımdan evrensel olanla kültürel ve bireysel

5 Friedrich Nietzsche, Tragedyanın Doğuşu, çev. İsmet Z. Eyüboğlu (İstanbul: Ataç Kitabevi, 1965), 15.

6 Ahmet H. Tanpınar, XIX. Asır Türk Edebiyatı Tarihi (İstanbul: Çağlayan Kitabevi, 1988), 61.

7 Edward B. Tylor, Primitive Culture (Part I) (London: John Murray, 1871), I.

8 Stuart Hall, Representation: Cultural Representations and Signifying Practices (London: Sage, 2003$), 1$.

9 Paul Thagard, "Cognitive Science", The Stanford Encyclopedia of Philosophy (Spring 2019 Edition), Edward N. Zalta (ed.), https://plato.stanford.edu/archives/spr2019/entries/cognitive-science/.

10 Lisa Zunshine, "Theory of Mind and Fictions of Embodied Transparency" Narrative 16/1 (2008), 6, 69. 
bakımdan özel olan arasındaki geçici fakat anlamlı ilişkilerin ortaya çıkışı, dışavurumları ve okunma biçimlerine dair yeni yaklaşımlar geliştirmektir" ${ }^{11}$.

İnsanın var oluşunu anlamlı hale getiren gerçekliklerden biri onun bedensel varlığıdır. Varlığın beden(sel) hâli, insanla birlikte kültürün simge değeri taşımasının belki de ilk koşullarından biri olmalıdır. Çünkü Yunus Emre'nin diliyle, ete kemiğe bürünüşümüzün simgesi olan beden, "Yunus diye göründüm" sözündeki görünür oluşumuzu temsil eder. Birçok yönüyle gizemli ve bundan dolayı anlaşılması ve anlamlandırılması şart olan bir simgesel alana dönüşen beden, kültürün dil üzerinden kodlanması için biçilmiş bir kaftan olarak karşımıza çıkar. Modern bilişsellik kuramlarından cisimleşen bilişsellik kuramı (embodied cognition) da, çevremizdeki durum, olay, davranış ve olguları anlamlandırmada bedensel varlığımızın önemine vurgu yapar. Buna göre, bütün bunlara bakışımız, kültürümüzün bedene dair oluşturduğu kavramsallaştırmalarımızla yakından ilgilidir ${ }^{12}$.

Cisimleşen bilişsellik kuramına göre, kavramsal sistemlerimizi bir arada tutan yapılar cisimleşen deneyimlerimizle biçimlenmekte ve bu deneyimler sayesinde anlam kazanmaktadır. $\mathrm{Bu}$ deneyimlerimiz, bedensel farkındalığımızdan (yeme-içme vb.) uzamsal ve durumsal farkındalığa (dikeylik vb.) kadar uzanır [...] Kuramın vurguladığı diğer bir nokta, dili anlamlandırmada duyusal ve deneyimsel yanlarımızın oynadığı roldür. Buna göre sanat eseri anlamlandırılırken soyut olandan somuta/cisim değeri taşıyana bir aktarım söz konusudur. Werner ve Kaplan buna 'fizyognomik algı' adını verir. Bu olguyu irdeleyen Berntsen'e göre, bu algı bağlantısız bir metni estetik bir objeye dönüştüren önemli mekânizmalardan biridir ${ }^{13}$.

1950’lerde bilişsel devrim (cognitive revolution) olarak adlandırılan süreçle birlikte modern bilişsellik çalışmaları da bedeni yeni bazı kavramsallaştırmalar penceresinden anlamlandırmaya ve yorumlamaya başlamıştır. Mark Johnson'ın deyişiyle, “insan bedeninin oynadığı başat rol, şeyleri [en geniş anlamda varlığı] kendimiz için nasıl anlamlı kılacağımızı da belirler"14. Diğer yandan, "ritüelistik bağlamda bedenin biçimlendirilmesi, safi bir yüzeysel işaretleme ya da kinestetik bir pratik değildir; çünkü, beden safi bir biyolojik organizma değildir; yerine, beden ancak analitik düzlemde mental, duyusal, duygusal, kinestetik ve yüzeysel olarak ayrıştırılabilecek; onun dışında her durumda eş zamanlı ve etkileşimsel bütüncül bir bedenleşme deneyimidir" ${ }^{15}$. Modern düşüncenin beden algısında yarattığı dönüşüm ve oynamaya başladığ 1 başat rol, özünde insanın yalnızca bedenine değil, çevresindeki bütün bir varlığa bakışının

11 Ellen Spolsky, The Work of Fiction: Cognition, Culture, and Complexity (London: Ashgate, 2004), viii.

12 George Lakoff, Mark Johnson, Philosophy in the flesh: The embodied mind and its challenge to Western thought (New York: Basic Books, 1999).

13 Murat Lüleci, Gülün Tam Ortası: Bilişsel Yazınbilim ve İkinci Yeni’nin Bilişsel Temelleri (Ankara: Grafiker Yayinları), 23.

14 Mark Johnson, The body in the mind: The Bodily Basis of Meaning, Imagination, and Reason (Chicago and London: The University of Chicago Press, 1987), xix.

15 Zehra Kaderli, "Kültürel Söylemlerin Biçimlendirme Yerlemi Olarak Beden ve Çağdaş Beden Modifikasyonlarının Fenomenolojik Boyutları" folklor/edebiyat 94/2, (2018), 164. 
yalnızca somutlaşmış hâlini sembolize eder. Bedenin kültürle ilişkisinin sorgulanmaya başlandığı böyle bir aşamada, Batı-dışı kültürlerin ve Batı-dışı modernite kavramının karşımıza çıkması son derece doğaldır.

\section{Batı-Dıșı Modernite}

Batı-dışı modernite kavramı, Batı'nın dışında kalan toplumların modernleşme süreçlerinin anlaşılması için verimli bir kavramsal çerçeve sunar. Bu kavramsallaştırma "meseleyi içinden anlamaya çalışmak[la]” eşdeğerdedir ${ }^{16}$. Batılı sosyologlar toplumsal değişimleri Batı-merkezci bir anlayışla ele aldıklarından, modernleşmenin de küresel ve homojen bir gelişim sergileyeceğine inandılar. Karl Marx’ın Das Kapital'de sanayileşmiş ülkenin, az gelişmiş ülkeye yalnızca kendi geleceğinin imgesini göstereceğine dair düşüncesi, Batı'nın kendisini önceleyen tavrının göstergesidir ${ }^{17}$. Max Weber için de modernite akılcılık demektir ve bu temel prensibi esas alan bütün toplumlar için gelenekselden moderne geçiş benzer bir gelişim gösterecektir. Marx da Weber de modernleşmenin evrenselliği düşüncesini ima ederler. Bu, Stuart Hall'un hegemonya kavramını çağrıştıran bir egemen kültür söylemidir. Oysa Osmanlı-Türk modernleşmesi Batı'dan çok farklı bir deneyimdir. Böylelikle bu şartlar, Batı-dışı modernite kavramını hazırlamıştır.

Batı 20. yüzyılda bir yandan büyük anlatılara -örneğin kutsal kitaplar, Marx ve Freud'ainancını büyük ölçüde yitirip Nietzsche'nin deyişiyle Tanrı'yı öldürürken, diğer yandan yeni anlatılar da yaratmıştır. Françis Fukuyama'nın tarihin sonunun geldiğine dair düşünceleri, bu türden bir üst anlatıdır ${ }^{18}$. Bu görüş, Batı-dışı bir modernite olamayacağı gibi, liberal demokrasi dışında bir yönetimin de olamayacağını savunurken, kendi var oluşuyla derin bir çelişkiye düşer. “Fukuyama'nın 'tarihin sonu' tezi liberal dünya görüşünün ve piyasa ekonomisinin modern dünya içerisindeki zaferini işlemekte ve bunun sonucu olarak farklı görüşler arasındaki çatışmanın sona erdiğini ve sanayi toplumları arasında benzeşme ve homojenleşmeye yol açtığını ileri sürmektedir" 19. Oysa "insan toplulukları, kişilik/kimlik algılarının, sosyal ilişkilerinin, zihinsel durumlarının, iyi-kötü algılarının, moral değerler ve alışkanlıklarının farklı biçimlerde tarif edildiği dilleri ve algı biçimleri olan çok kültürlü bir katmanı işaret eder"20. Türk modernleşmesi de bu türden bir okumanın ürünüdür.

\section{Türk Modernleşmesi}

Türk kültürünün son birkaç yüzyılını derinden etkileyen modernite, “on yedinci yüzyılda Avrupa'da başlayan ve sonraları neredeyse bütün dünyayı etkisi altına alan toplumsal yaşam ve

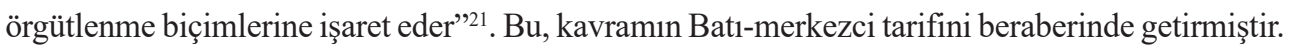

16 Şerif Mardin, Türkiye 'de Toplum ve Siyaset, der. M. Türköne-T. Önder (İstanbul: İletişim Yayınları, 1990$), 106$.

17 Karl Marx, Capital: A Critique of Political Economy (New York: Random House, 1906), 13.

18 Françis Fukuyama, The End of History and The Last Man (New York: The Free Press, 1992).

19 Nilüfer Göle, "Batı Dışı Modernlik: Kavram Üzerine”, Modern Türkiye’de Siyasî Düşünce, editörler: Tanıl Bora, Murat Gültekingil (İstanbul: İletişim Yayınları, 2002), 56.

20 Charles Taylor, "Two Theories of Modernity” The Hastings Center Report 25/2 (1995), 24.

21 Anthony Giddens, Modernliğin Sonuçları, çev. Ersin Kuşdil (İstanbul: Ayrıntı Yayınları, 2004), II. 
Oysa Türk modernleşmesi, hem toplumsal düzeyde hem de sanat ve edebiyatta kendisini batıdan farklı bir temel üzerine inşa eder. Buna rağmen Türk romanının Türk modernleşmesi bağlamında özgül şartları yeterince irdelenmemiş, roman üzerinde bir bilişsel kültür okuması gerçekleştirilmemiştir. Oysa uzun bir anlatı/anlatma geleneğine sahip olan Türk romanında bilgi ve varlık sorunsalları oldukça özgün bir değişimden geçmiştir. Foucault'nun Bilginin Arkeolojisi'nde ortaya koyduğu episteme ve Daryush Shayegan'ın Yaralı Bilinç'teki ontolojik kopuş kavramlarından hareketle çözümlendiğinde, Türk romanının farklı epistemolojik ve ontolojik bir dizge doğrultusunda hareket ettiği görülmekte, kendine özgü bir bilgi ve varlık çizgisinde ilerlediği anlaşılmaktadır.

Şerif Mardin, Türk Modernleşmesi'nde Türkiye'de ekonomik dönüşümden söz ederken, "Osmanlı ve Türk tarihinin özgüllüklerini hesaba katan bir modelden" hareket edilmesi gereğinin altını çizer: "Siyasal iktidar etrafında yapılanmış ve dinsel-etnik birimlerden oluşmuş bir sistemden üretimin ve işlevsel iş bölümünün eski yapı içine yerleştirildiği bir sisteme geçiş, Türkiye'nin 'modernleşme' tarihinde mutlaka merkezî bir konuma sahiptir. Bu boyutu ihmal edenler geçişte içerilen sistematik değişimi anlayamazlar"22. Modernleşen Türk romanında bilgi ve varlık problemi de tıpkı üretim ilişkilerinde olduğu gibi, dinî-etnik inanç kodlarının ağırlıkta olduğu bir sistemden, duygu, düşünme ve davranma biçimlerinin eski yapı içine yerleştirildiği bir sisteme geçiş olarak kendisini göstermiştir.

Türk modernleşmesi, epistemolojik bakımdan bilgi kaynaklarının çoğaldığı ve bulanıklaştığı, ontolojik bakımdan varlığın bir kopuşa sahne olduğu bir sürecin tarihidir. Bu nedenle Türk modernleşmesi özel bir okuma ile değerlendirilmeli, kültürün buradaki önemli rolü teslim edilmelidir. Oysa yirminci yüzyıl sosyal bilimcileri Batı-dışı moderniteden büyük oranda yüz çevirmişlerdir. Örneğin René Girard'ın teorisi kültürel farklılığa yer vermez. Çünkü kendisinin farkında değildir, bu nedenle de Batıyı önceleyen bir anlayışla yazmaktadır ${ }^{23}$. Türk modernleşmesinin özgül koşullarının ortaya konabilmesi, Batı'nın oryantalist bakışının ardındaki güç zehirlenmesine karşı bir panzehir üretecek olması yönüyle de son derece önemlidir. Mardin’e göre: "birçok roman yazıldıkları zamana ait İstanbul seçkin çevrelerinin durumu hakkında bize önemli bilgiler verir". Ayrıca, bu kaynaklar Osmanlı aydınlarının toplumsal değişmenin ortaya çıkardığı sorunlara yaklaşım biçimlerini gösteren birer belge niteliğindedir"24. Böylece Osmanl1-Türk modernleşmesi Batı-dışı bir modernite olarak temellendirilmiş olacaktır.

\section{Bilişsel - Kültürel Bir Simge Alanı Olarak İnsan Yüzü ve Bedeni}

Platon'un Diyaloglar'ı fizyonomi üzerinden karakter oluşturmada ayrıcalıklı bir önem taşır. Lukács, Platon'un Symposion diyalogunda Socrates, Alcibiades, Aristophanes gibi tarihi şahsiyetlerin karşımızda bütün canlılıklarıyla durduğunu, bunu sağlayan şeyin de entelektüel fizyonomilerinin ortaya konması olduğunu söyler. Ona göre, Diderot ve Balzac'ın eserlerinde

22 Şerif Mardin, Türk Modernleşmesi (İstanbul: İletişim Yayınları, 1991), 206.

23 Orhan Koçak, "Kaptırılmış İdeal: Mai ve Siyah Üzerine Psikanalitik Bir Deneme”, Toplum ve Bilim 70 (1996), 121.

24 Mardin, Türk Modernleşmesi, 32. 
karakterler, soyut konular karşısında dinamik-kişisel ve hayati öneme sahip tavırları ile canlılık kazanır, bu nedenle entelektüel fizyonomi canlı karakterler üretmede birinci derecede önemlidir ${ }^{25}$. Fransız kralı XIV. Louis'nin doktoru Marin Cureau De la Chambre, L'Art de connaître les hommes adlı kitabına şu satırlarla başlar:

Doğa insana düşüncelerine tercüman olsun diye sadece ses ve dil vermedi, onları kötü niyetle kullanır şüphesiyle, insanın alnını ve gözlerini de konuşturdu. Kısacası bütün ruhunu dışına yaydı. Ruhun kıpırtılarını, zaaflarını, alışkanlıklarını görmek için pencereye hiç gerek yoktur, çünkü hepsi de yüzde zuhur eder bunların ve hepsi gayet okunaklı, açık seçik harflerle oraya yazılmışıtır ${ }^{26}$.

Halit Ziya da İlm-i Sîma'sında bu ilmi, “Allah'ın kudret elinin, beşerin ruhî hallerinin bir yansıma yeri olmak üzere nakş ettiği yüzün alametleri ile iç yüzünde saklı olanları göstermek iddiasında bulunan bir ilim" olarak tanımlar. Lavater' in Physiognomische Fragmente'si Halit Ziya'yı etkilerken, yirminci yüzyılda yapılan fizyonomi çalışmaları, bu araştırmaya da konu olan Peyami Safa'yı ve onun karakterizasyonunu derinden etkilemiştir. Safa'nın da düşüncelerini onayladığı, dönemin en ünlü fizyonomistlerinden Fransız psikolog Louis Corman'a göre burnun, kulakların, elmacık kemiklerinin ve gözlerin yer aldığı orta kısım, Duygusal Yaşam Alanı'nı belirlerken, kaşların, alnın yer aldığı ve Kültürel Yaşam Alanı olarak adlandırılan üst kısım da düşünce hayatını belirler ${ }^{27}$. Corman'ın düşüncesinde yüzün duygusal ve kültürel yaşam alanlarımızla çok yakından ilgisi bulunmaktadır.

\section{Fizyonominin Envanteri}

Fizyonomimiz kültürel durumumuzla yakından ilgilidir ve kültür fizyonominin başlıca değişkenleri arasındadır. Zira kültür, davranışlarımız gibi, yüz ve bedenlerimize yüklediğimiz anlamlara ait değişkenlerin başında yer alır. Baumbach, çalışmasının "Fizyonomik Envanter" adını verdiği bölümünde bir yandan "gözler"i "ruha açılan pencere" olarak tanımlarken, diğer yandan Shakespeare'in, Macbeth'te, insan yüzünü “gizemli anlamların okunduğu bir kitap" olarak metaforlaştırdığını hatırlatı228. Yazınsal metnin anlamı, nasıl onu meydana getiren parçaların anlamından bağımsız değilse insan yüzü ve bedeni de belli bir kontekst çerçevesinde gerçek anlamını bulur. "Çökük bir alın ve sıcaklıktan yoksun gözler yüzün öteki çizgilerinden bağımsız olarak ele alındıkları zaman özünlü bir anlam taşırsa da gözlerin ve alnın geri kalan çizelerle bağıntıları içinde bu anlam değişebilir: kesin anlamları her zaman içinde belirdikleri bütünün işlevidir" ${ }^{29}$. Courtine'in deyişiyle,

25 Georg Lukács, Writer \& Critic and Other Essays (New York: The Universal Library, 1971), 150.

26 Alain Corbin, Jean-Jacques Courtine, Georges Vigarello, Bedenin Tarihi-1: Rönesans 'tan Aydınlanma'ya, çev. Saadet Özen (İstanbul: Yapı Kredi Yayınları, 2007), 249.

27 Ernst Kretschmer, Beden Yapısı ve Karakter: Konstitüsyon Meselesi ve Mizaçlar Bilgisi Hakkında Araştırmalar, çev. Mümtaz Turhan (İstanbul: İÜ Edebiyat Fakültesi Yayınları, 1949), 156.

28 Baumbach, Shakespeare and the Art of Physiognomy, 120.

29 Yücel, Insanlık Güldürüsü'nde Yüzler ve Bildiriler, 24. 


\begin{abstract}
Ruhun krallığı — karakter özellikleri, tutkular, eğilimler, duygular, heyecanlar, psikolojik doğa—ile bedenin hükümranlığı —işaretler, izler, nişaneler, göstergeler, fiziksel özelliklerarasındaki ilişki. İnsanın bilginin bu apayrı alanlarından beslenen ve onları birleştiren dışa vurum tarzını özetleyen o kadim metaforların da dile getirdiği budur ki fizyognomoni de bunların en sistemli ifadesidir: bu bağlamdaki bakışlar, 'kapıdır', 'pencere' ise yürek; yüz 'ruhun aynasi', beden 'tutkuların sesi'ya da 'sureti ${ }^{30}$.
\end{abstract}

Böylelikle, kültürü fizyonomik anlamın derin konteksti biçiminde tanımlamak mümkün hâle gelir. İnsan bedeninin en ayırt edici bölümlerinden biri olan yüz klasik dönemden itibaren derinlikli çağrışım alanları olan bir anahtardır. William Hogarth The Analysis of Beauty'de yüzü, "zihnin fihristi” olarak tanımlar ${ }^{31}$. David Le Breton, onu, "insanın en insanca bölgesi" olarak görür. Yüz aynı zamanda toplumsal ve kültüreldir: "Mimiklerimizin, duygularımızın, görünüşümüzün (saç biçimi, makyaj vs.) sahnelendiği yüzümüz, toplumsal bir simge alanına bağlıdır"32. Böylece yüz yalnızca kişisel duygu durumunu yansıtan bir aynaya değil, aynı zamanda kültürü yansıtan bir göstergeye dönüşür.

Yüz toplumsal ve kültürel olanın bir arada simgeleştiği bir haritadır. Le Breton bu durumu şöyle dile getirir: "Toplumsal simgecilik ötekinin bakışının aşinalığını oraya kaydetmek üzere göstergelerini yüze serpiştirir. (...) Yüzde görünen her şey bir tanınma göstergesinin görüntüsüdür. Mizanseninin (makyaj, bıyık, sakal, saç kesimi vb.) mimik üretiminin, başkalarına bakışın belli bir biçimde yapılması, onun anında bir dizi anlamla birleştirilmesini sağlayan bildik apaçıklığın merkezine dönüştürür. Yüz asla bir doğa değildir, o bir kompozisyondur. Gerek insanın kendinin farkında olmasına, gerek anlaşılması güç toplumsal ve kültürel etkiye zemin oluşturur. Sosyolojinin ve antropolojinin gösterdiği gibi, toplumsallaşma insanın bedensel anlarında özel yaşamının en gizli noktalarını biçimlendirir, yüzü de es geçmez". ${ }^{33}$ Yücel'in deyişiyle, "yazgının ve yaşamın göstergeleri aynı yüzde kesişir, iç içe girer, birbirine dolaşır, böylece onu karmaşık bir anlam alanı, iki düzey üzerinde eklemlenen bir dile dönüştürür" ${ }^{34}$.

Yüzün en dikkat çekici bölümlerinin başında gelen göz aracılığıyla gerçekleşen görme eylemi de her şeyden önce zihinsel bir etkinliktir. "Cicero en keskin duyumuz görme duyusudur, diye yazmıştır. Göz, sahip olduğu çağrışım alanlarının genişliği sayesinde evrensel bir öneme sahiptir. Bilindiği gibi, göz birçok kültürde 'ruha açılan pencere' olarak algılanır. Bununla birlikte göz ve bakışın farklı kültürlerde başka anlamsal alanlara karşılık geldiğini görürüz. Göz, romanda karakterizasyon ve özneler arası iletişimde de önemli rol oynar. O "insan yüzünün en anlamlı öğelerinden biridir: [çünkü] devinim ve anlatımlarının zenginliğiyle yüzün tüm

30 Courtine, Bedenin Tarihi-1, 250.

31 William Hogarth, The Analysis of Beauty (London: W. Strahan, 1753), 125.

32 Breton, Yüz Üzerine Antropolojik Bir Deneme, 11-16.

33 Breton, Yüz Üzerine Antropolojik Bir Deneme, 144.

34 Yücel, Insanlık Güldürüsü'nde Yüzler ve Bildiriler, 122. 
öteki öğelerinden ayrılır"35. Aziz Augustine gözlerimizi dünyanın giriş kapısı olarak önce övmüş, sonra da lanetlemiştir. Aguino'lu Aziz Tomasso görmeyi ‘bilgi edinmemizi sağlayan duyuların en büyüğü’ olarak tanımlar" ${ }^{36}$. Gözleri, insan yüzünün en derin anlam katmanlarına sahip bölümü olarak görmek mümkündür.

Görme bir duyu olduğu kadar bir deneyimdir de ve bu deneyimin kültürel boyutundan da söz etmek gerekir. Martin Jay, gözün yalnızca 1şık ve renkleri edilgen bir şekilde algılayan bir reseptör olmadığını, aynı zamanda kendini en fazla ifade eden, belki zaman zaman ele veren, duyu organı olduğuna dikkati çeker ${ }^{37}$. Onun yürüttüğü mantığı devam ettirerek söyleyecek olursak dilimizde yer alan "kalp gözü”, "gözler yalan söylemez”, "gözler kalbin aynasıdır” gibi söyleyişler de şüphesiz birer "sembolik gerçeklik"e karşılık gelmektedir. Gözün sembolik bir gerçekliğe karş1lık gelmesi, bizi gözün kültürle olan ilişkisine götürür. Göz, benzerlik ilişkisini algılayan ilk duyu organıdır ve metafora kaynaklık eden bu algıda meydana gelen değişimler, kültüre de doğrudan yansır.

Vücudun, varlıkla ilişkisi, hareket, duruş ve tavırlarının belli anlamlara karşılık gelecek biçimde algılanmasını sağlamıştır. Zihnimiz bedenimizi duygunun yansıtılmasının yollarından biri olarak algılar. Breton, antropolojik açıdan beden imgesinin birbirine dolanmış dört simgesel işlev çevresinde yapılandığını belirtir. Bu işlevlerden bilgi ve de ğer işlevlerinin toplumla ve kültürle yakından ilişkilidir. Bilgi işlevi, "kişinin bağlı olduğu toplulukta dolaşımda olan ve kendisine bedeninin görünmez iç yüzünün neden, ne gibi maddelerden oluştuğunu açıklayan beden kuramına (ya da kuramlarından birine) başvurması[n1]" ifade eder ${ }^{38}$.

İnsanın yüzü ve bedeninin simgesel bir anlama karşılık geldiği böyle bir kavramsal çerçevede, fizyonominin anlatı metinlerindeki görünümleri de kültürün değişen dinamiklerinin ortaya konmasında kilit bir öneme sahiptir. Bu nedenle Türk romanında yüz ve beden biçimlerinin çözümlenmesi romanımızın epistemolojisi ve ontolojisinin ortaya konması için bir anahtar hükmü taşımaktadır.

\section{Epistemin Yerçekimini Kaldırmak: Halit Ziya'da Bilginin Değişen Arkeolojisi}

Türk romanı, Tanzimat'ın ardından Osmanl1-Türk kültürünü ya da Doğu-İslam epistemolojisini devam ettirmekle birlikte yeni bir epistemoloji geliştirmiş, bu yeni algı tarzı romanda karakterlerin yüz ve beden biçimlerine yansımıştır. Zira "Bir edebiyat eserinde bulunan her bir unsur, örneğin romandaki bir karakter veya küçük bir eşya, yazarın genelde dünyayı, özelde ise çevreyi nasıl algıladığını gösterdiği gibi, eserin yazıldığı dönemdeki siyasal ya da toplumsal bir takım özellikleri belirlemeyi de kolaylaştırır"39. Fizyonomi üzerinden

35 Yücel, Insanlık Güldürüsü'nde Yüzler ve Bildiriler, 55.

36 Alberto Manguel, Okumanın Tarihi, çev. Füsun Elioğlu (İstanbul: Yapı Kredi Yayınlar1, 2013), 44.

37 Martin Jay, Downcast Eyes: The Denigration of Vision in Twentieth-Century French Thought (Berkeley and Los Angeles: University of California Press, 1994), 9.

38 Breton, Yüz Üzerine Antropolojik Bir Deneme, 316.

39 Salim Çonoğlu, "Servet-i Fünûn Romanında Beden Yapısı, Bedensel Davranışlar ve Kişilik İlişskileri Üzerine Bir Çözümleme”, Yeni Türk Edebiyatı Araştırmaları 1, (2009), 59. 
gerçekleştirilecek bir yakın okuma da, bu epistemolojinin hangi izleklerden geçerek evrildiği sorusunun cevaplanmasını sağlayacaktır.

Türk romanını ayrıcalıklı kılan, bu roman geleneğinin birbirinden farklı epistemolojilerden beslenmesi ve çok tabakalı bir değişim çizgisi göstermesidir. Jale Parla Tanzimat romanını baba-oğul problemi üzerinden temellendirmiş, bu problemi bir "köksüzlük" izleği çerçevesinde çözümlemişti ${ }^{40}$. Shayegan'ın yaralı/yaralanmış bilinç olarak temellendirdiği ve Jale Parla'nın köksüzlük üzerinden okuduğu gerçeklik, aslında modernitenin farklılaşmış deneyimlerinin ifadesidir. Tanzimat'ın bu ilk kurucularının ardından epistemoloji ne yönde gelişmiş, Tanzimat'ın “Oğul”larının ardından Tanzimat'ın torunları nasıl bir epistemoloji meydana getirmişlerdir? Yakın okumalarımız, Halit Ziya’nın romanlarının bu konuda kilit öneme sahip olduğunu göstermektedir.

Türk romanında Halit Ziya’nın romancılığının ayrıcalıklı bir yeri vardır. Tanpınar, bu yeri, “[b]izde asıl romancılık Halit Ziya ile başlar”, sözleriyle dile getirir ${ }^{41}$. Halit Ziya'nın, en sevdiği yazarların başında adını zikrettiği Balzac, canlı karakter oluşturmada Batı romanının en güçlü kalemlerinden biridir. Onun "dünyasında, yüzün hem içe, hem dışa açılan, devingen öğesi ağız nasıl dışsallaşmış yürekse, bir başka açık ve devingen öge olan göz de insanın 'görünür tini’ olarak tanımlanır" "42. Halit Ziya, Balzac'1, "asarının semere-i hayalat değil, bir mahsul-1 tedkikat-ı hikemîye olmasını arzu ediyor, bu arzuya çalışıyordu" sözleriyle anlatır ${ }^{43}$. Ona göre, Balzac'ın karakterleriyle karşılaşan okuyucu, olaylar gelişirken, karşılarında gerçek hayattan br kesit izledikleri ve karakterlerin kalbinin çarptığı hissini yaşamaktadır.

Halit Ziya, Doğu-İslam kültüründen modern bir duyuş-davranış tarzına doğru değişen genetiğimizin insanımız üzerinde yarattığı dramatik etkiyi kurgusal belleğine yansıtmıştır. Tanzimat'ın temsilcisi konumundaki Ahmet Mithat ile yeni duyuş tarzının temsilcisi durumundaki Edebiyat-1 Cedidecileri ayıran en önemli nokta Tanzimat ile sonrasında aydının sahip olduğu bu epistemolojik tavırda gizlidir. Tanpınar'ın deyişiyle, "Bütün Ahmet Midhat Efendi'yi hiç olmazsa okudukları ile Dağarcık'ta bulmak mümkündür”. Tanpınar'a göre Efendi, “pozitivist felsefenin, Lamarkizmin verileriyle İslâmî esasları birleştirmeğe çalış[makta], hatta Kuran' da, Hadis’te onlara dayanak" aramaktadır ${ }^{44}$. Oysa Ahmet Cemil ile Hüseyin Nazmi, kendi edebiyatlarından sıkılarak Batı'ya yönelmiş, Fuzulî, Baki ve Nedim gibi eski edebiyatımızın temsilcilerinin eserlerini yakarak Batı edebiyatına açılmışlardır. Okudukları arasında, Goethe ve Schiller başta olmak üzere, neredeyse bütün Fransız sembolistleri de vardır. Bütün bunlar, Tanzimat'ın ardından bilginin akışında meydana gelen/gelecek köklü değişimlerin habercisidir.

Ahmet Cemil üzerinden verilen bu yeni bilme durumu, Halit Ziya'nın romancı tavrına doğrudan yansımıştır. Yeni roman "hazırlop anlamlar” sunmaz; "basit bir yelek hem bir

40 Jale Parla, Babalar ve Oğullar: Tanzimat Romanının Epistemolojik Temelleri (İstanbul: İletişim Yayınları, 2008).

41 Ahmet Hamdi Tanpınar, Edebiyat Üzerine Makaleler (İstanbul: Dergâh Yayınları, 2014), 284.

42 Yücel, Insanlık Güldürüsü'nde Yüzler ve Bildiriler, 95.

43 Halit Ziya Uşaklıgil, Hikâye (İnceleme), haz. Nur Gürani Arslan (İstanbul: YKY, 1998), 58.

44 Tanpınar, XIX. Asır Türk Edebiyatı Tarihi, 449. 
karakteri, hem de toplumsal bir durumu belirt[ebilir]" ${ }^{45}$. Ahmet Cemil'in Beyoğlu'nda en sevdiği yer olan Luxsenburg cafe'nin ön tarafinda bir yere oturduğunu, aşağıdan yukarıya geçen halkı seyrettiğini ve binlerce yolcu arasından seçtiği yüzleri takip ettiğini öğreniriz:

Orada ön tarafta bir yere oturur, önünden aşağıdan yukarıya geçen halkı seyreder, bu binlerce yolcudan intihap ettiği bazı çehreleri oturduğu yerin mahdut nezareti dairesinin müsade ettiği kadar takip eder; o çehrelerin kimisinin paltosundan, kimisinin eski elbisesinden, birisinin elindeki paketten bir kadının yanındaki çocuktan mânalar anlar; zihnen bir dakikalık zaman içinde bu çehreler için birer mufassal hikaye yazard ${ }^{46}$.

Ahmet Cemil diğer insanların bakışlarından anlam çıkarmakta, eylem ve davranışlarını yorumlamakta, bedenlerinin duruşlarına anlamlar yüklemekte, başka bir deyişle fizyonomilerini yorumlamaktadır. Alain Robbe-Grillet, Balzac'ın romanlarının yüz ve vücutların yanı sıra, "uzun uzadıya ve kılı kırk yararcasına tasvir edilmiş evlerle, döşemelerle [ve] elbiselerle" dolu olduğunu söyleyerek bu tasvirlerin amacının göstermek olduğunu vurgular ${ }^{47}$. Gözlemlediği insanların elbise ve yüzlerinden anlamlar çıkaran Ahmet Cemil, Halit Ziya'nın karakterlerini anlatmaktan çok göstermek isteyen tavrının ürünüdür. Halit Ziya, Mâi ve Siyah'tan "yakından müşahadeler üzerine vücuda gelmiş bir vesika" olarak söz eder ${ }^{48}$. Böylece Halit Ziya, Mâ̂ ve Siyah ile birlikte fizyonomi sahnesine ilk adımını atmıştır.

Bir eski elbisenin metnin anlamına katkı sunduğu Halit Ziya'nın dünyasında yüz ve bedene ait görünümler, onun "kesin çizgili karakterler" yaratmasını sağlamıştır". Anlatmak yerine göstermenin esas olduğu bu tavır, anlamın mutlak ve değişmez olduğu bir kaynağın değil, bir yüzün ve bedenin sahipliği iddiasındaki öznenin fizyonomisinde açığa çıkan yeni bir epistemolojinin habercisidir. Onun, kurgusal dünyasında fizyonomiyi etkinleştirmesinin epistemolojik bakımdan ne anlama gelebileceğini araştırmak için Foucault'nun tarihsel a priori ve arşiv kavramlarına uzanacağız. Tarihsel a priori, "ifadelerin ortaya çıkış koşullarını, onların başka ifadelerle birlikte varoluş yasasını, varolmak kiplerinin özel biçimlerini, kendilerine göre varoldukları, dönüştükleri ve ortadan kayboldukları ilkeleri ayırdetmek[tir]" ${ }^{50}$. Arşiv ise, "öncelikle söylenebilen şeyin ilkesi, ifadelerin bireysel olarak ortaya çıkışını yöneten sistem" olarak tanımlanır ${ }^{51}$. Foucault, arşivi toplumsal bir koşullanma ya da bilinçaltında oluşan, adeta içgüdüsel kurallardan oluşan bir bütün olarak algılar. Bu açıdan bakıldığında, kültürü yansıtması bakımından bir ayna işlevi gören yazınsal metnin söylemini düzenleyen kurallar da bilincin dışında bir yerlerde yazılmaktadır. Foucault’nun kavramsallaştırması ile

45 Alain Robbet-Grillet, Yeni Roman, çev. Asım Bezirci (İstanbul: Yazko, 1981), 49.

46 Halit Ziya Uşaklıgil, Mai ve Siyah, (İstanbul: İnkılap ve Aka Kitabevleri, 1968), 91.

47 Robbet-Grillet, Yeni Roman, 48.

48 Nihat Sami Banarl1, Resimli Türk Edebiyatı Tarihi (İstanbul: MEB Basımevi, 1971), 1052.

49 Banarl, Resimli Türk Edebiyatı Tarihi, 1053.

50 Michel Foucault, Bilginin Arkeolojisi, çev. Veli Urhan (İstanbul: Ayrıntı Yayınları, 2019), 164-5.

51 Foucault, Bilginin Arkeolojisi, 167. 
düşünülürse, bunun insiyaki biçimde kendiliğinden olduğunu söyleyen Halit Ziya'nın tavrı çok daha anlamlı hâle gelmektedir.

Mai ve Siyah'ta söylemi düzenleyen yasaların, salt bilincin dışında, belki de bilinçaltından kaynaklandığını görürüz. Orhan Koçak, Mai ve Siyah'a dair gerçekleştirdiği psikanalitik çözümlemesinde, Edebiyat-ı Cedide romanı çevresinde oluşan önyargının asıl direncini "Osmanlı-Türk modernleşmesinin özgül koşullarından al[dığını]” söyler ${ }^{52}$. Bu özgül koşullardan biri karakterler arasındaki iletişimin, zaman zaman, sözsüz, yalnızca yüz ve beden biçimleri üzerinden gerçekleşiyor olmasıdır. Halit Ziya'nın deyişiyle şiir idealinin sembolü olan Ahmet Cemil, bu ideali dillendirirken, yine fizyonomiye yakın bir dikkat sergiler. Mâi ve Siyah'ta “Bilseniz! Şiirin nasıl bir lisana muhtaç olduğunu bilseniz!" biçiminde seslenen Ahmet Cemil’in yaklaşımı roman ve romancının, insanın "hâllerini" ifade etmede sahip olduğu imkânlar çerçevesinde değerlendirilmelidir. Ahmet Cemil'in sözünü ettiği lisan “öyle bir lisan[dır] ki, ... Onda o nağmeler, o renkler, derinlikler olsun; müteverrim bir kızın kenar-1 firâşına düşsün, ağlasın; bir çocuğun mehd-i naz-perverine eğilsin, gülsün; bir gencin nur-ı nigâh-1 şebâbına saklansın, parlasın"53. Burada sözü edilen dilin, öznenin zihinsel durumuna uygun biçimde sembolleştirilmesinin gerekliliğidir. Başka bir deyişle "Ahmet Cemil'in özlediği şey, insanoğlunun bütün duygularını ifade eden bir dil vücuda getirmektir" ${ }^{54}$. Hastalık, masumiyet ve umut birer duygu ya da "hâl"dir ve Ahmet Cemil bunlara ağlama, gülümseme ve bakış olarak dile gelmesini istemektedir. Bunların dile gelmesinin yolu ise bir kurgusal karakterin yüz ve bedeninin, o duyguları yansıtacak biçimde kodlanmasıdır. Lisan da böylece "serâpâ insan" olacaktır.

Ahmet Cemil'in hayalini kurduğu dilin başlıca özelliği, farklı bir modernite çizgisinden gelen kendine has bir tavrın karakterlerin yüz ve bedenlerinde kodlanmış biçimde vücuda gelmiş olmasıdır. Ahmet Cemil başta olmak üzere, romanın karakterlerinin insanlık durumlarına - hayal kırıklıklarına, kısa süren mutluluklarına - büyük oranda bu türden bir dil eşlik eder. Ahmet Cemil, önce Lamia’nın güler yüzlü bakışının kalbinde bir demet mutluluk çiçeği gibi büyüdüğünü hissedecek fakat romanın sonlarında Lamia'nın aynı bakışı hayal kırıklığı biçiminde Ahmet Cemil'in iç dünyasında kopan bir fırtınaya dönüşecektir:

Eğer Lamia bu anî nazar içinde ona küçük bir tesliyet mânası göndermiş olsaydı hepsini unutacak, yalnız o nazarın hatırasını bütün kırılan aşkının bir yadigârı kabilinden hayatının sonuna kadar saklayacak, ruhunun içine sararak bu yadigârı hayatının biricik saadet nasibesi hükmünde besleyecekti; fakat bu öyle bir nazar idi ki hiç bir şey ifade etmemekle beraber Ahmel Cemil'e bütün hulyasının bir yalan olduğuna şüphe edilmeyecek bir bedahetle şahadet etmişti ${ }^{55}$.

52 Koçak, Kaptırılmış İdeal, 94.

53 Uşaklıgil, Mai ve Siyah, 13.

54 Mehmet Kaplan, "Mâi ve Siyah Romanının Üslubu Hakkında", İstanbul Üniversitesi Edebiyat Fakültesi Türk Dili ve Edebiyatı Dergisi XIX (1971), 53.

55 Uşaklıgil, Mai ve Siyah, 218. 
Lamia'nın bakışı ile Ahmet Cemil'in bütün hülyasının yıkılması ve küçük bir kahkahası karşısında bile "bir husumet (...) tahammül edilemez bir işkence" duyması, anlamın üretilmesinde öznenin ve onun fizyonomisinin ön plana çıktığı yeni bir epistemolojinin yansımasıdır. Bu nedenle, "en çirkin bir hakikat[i] en süslü bir hayale müreccah" gören Halit Ziya, modern bir tavrın sonucu olarak karakterlerini anlatmayı değil, göstermeyi seçer. Öznenin, yüz ve bedenden yansıyan anlamın birincil yapıcısı olması bakımından Mai ve Siyah önemini korurken, Halit Ziya bu kez Aşk-ı Memnu' da karakter fizyonomisinin epistemolojik temelleri bakımından daha olgun örneklerle karşımıza çıkacaktır.

Halit Ziya'nın en olgun eseri olan Aşk-ı Memnu'nun başlıca özelliği, yazarının deyişiyle, “eşhasın çok olması ve her birinin hususî ve zatî bir hayat yaşamasıdır ${ }^{56}$. Tanpınar'a göre bu hususi ve zatî hayatların ardında "içtimai tenkit gayesi”" vardır. O, romanın yalnızca başlangıcının değil, bütününün bir boşluk ve kaçışı göstermek amacı taşıdığını dile getirir ${ }^{57}$. Aşk-ı Memnu' da karakterlerin yüz ve beden biçimleri, bu boşluk ve kaçışın gösterilmesinde çok önemli bir işlev görür. Halit Ziya dönemin insani durumunu fotoğrafik bir gözle kurgulamış; epistemolojik girdide yaşanan değişim, yüzün temsil biçimlerinde bariz biçimde kendisini göstermiştir. Örneğin bedenin de ruhun da dünyaya açılan penceresi olarak anılan "göz”, bu noktada önemli bir çıkış noktasıdır. "Ahmet Mithat'a göre 'kadınlar huzurunda gözlerini kaldırıp da yüzlerine dikkatlice bakmak bile mugayir-i edep addolunur' ${ }^{58}$. Oysa Intibah'1n Ali Bey'i Mahpeyker'le karşılaştığında, "gözünün, kaşının hâsılı kâffe-i azasının her hareketi istizân-i matlap için bir lisan-1 edeb olmuş idi" 59 .

Gözün edeb ile aşağı yönde hareketi, Zeynep Sayın'ın deyişiyle “bakışı azaltmak”tır. Böyle bir hâl ise "göz kapaklarını tevazuuyla indirmek demektir ve bakışın egemenliğine engel olmak içindir. Örnekse bu yüzden peygamberin sevindiği zaman gözlerini yarı yarıya kapadığı ifade edilir: "Göz kapağını kısar, başını aşağı doğru eğer ve gözlerini açmazdı" ${ }^{60}$. Oysa Aşk-ı Memnu'da okur bundan çok farklı bir fizyonomiyle karşılaşacaktır. Romanın dikkat çekici sahnelerinin birinde Bihter'le Behlül yalnızca gözleri ile birbirine gülümsemiş, fakat aynı anda Adnan Bey'in gözlerini de kendilerine bakıyor görmüşlerdir. İki özne arasında gerçekleşen bakışmanın, üçüncü bir özne tarafından fark edilmiş olması, Bihter için o kadar önemlidir ki, Bihter "o gün saatlerce kocasının üzerine yürüyerek ve ellerini kavrayarak 'bana hiyanet ediyorsun, bunu senin gözlerinde gördüm!' demesinden titre[miştir]”. ${ }^{61}$

Bihter'le Behlül'ün bakışırken fark edilmiş olmaları, Türk romanının değişen epistemolojisi bakımından tam bir dönüm noktasıdır. Halit Ziya Bey’in kahramanları, Ali Bey’in Mahpeyker karşısındaki utangaç tavrından çok farklı bir tavır içerisindedir. Nihal'in Bihter'e "muhteriz

56 Banarlı, Resimli Türk Edebiyatı Tarihi, 1053.

57 Ahmet Hamdi Tanpınar, Yahya Kemal (İstanbul: Dergâh Yayınları, 1995), 88.

58 Parla, Babalar ve Oğullar: Tanzimat Romanının Epistemolojik Temelleri, 80.

59 Namık Kemal, Intibah: Sergüzeşt-i Ali Bey, Haz. Mustafa Nihat Özön (İstanbul: Remzi Kitabevi, 1961), 60.

60 Zeynep Sayın, “Batı'da ve Doğu'da Bedenin Temsilinde Haysiyet ve Zillet II: İslami Beden Temsili: İffet ve Zillet” Defter 40 (2000), 203.

61 Halid Ziya Uşaklıgil, Aşk-ı Memnu, İbrahim Hilmi (İstanbul: Hilmi Kitabevi, 1945), 178. 
bir nazarla" bakması, Firdevs Hanım'ın “gözlerinin derinliklerinden kopup gelen bir süzgün ve sitemli nazarla Behlül'e" bakışı, Adnan Bey’le kızı Nihal'in “dik, titremeyen, husumeti andıran bir nazarla bakışmaları", kendisini var ederken farklı bir epistemolojiden hareket eden insanın ve artık değişmeye başlayan bir zihniyetin kodlarıdır.

Halit Ziya'nın romanında, birbirine keskin ve kızgın bakışlarla gözlerini dikmiş iki farklı paradigmanın çarpışması sahne alır. Shayegan eski ve yeni paradigmaların kesişe kesişe, sonunda birbirlerini biçimsizleştirdiğini söyler. Ona göre "Modernlik Geleneğin ölçüleriyle tartılmış, Gelenek de Modernliğin şiddetli çelmelerini yemiştir" ${ }^{62}$. Bu türden bir çelme aslında Tanzimat romanında itibaren kendisini gösterir. Intibah'ta Ali Bey, Mahpeyker tarafından bir "sevdâ-yı bîismetaneye" sürüklenerek ona düşman olmuş, Araba Sevdası'nın efemine Bihruz Bey’i Periveş Hanım tarafından aşkına karşılık bulamamıştır. Oysa Aşk-ı Memnu'da Behlül'ün bedeni üzerinden verilen zillet oldukça dikkat çekicidir:

Behlül, zannının tamamiyle hilafına olarak, Bihter'de yumuşak, gevşek bir kadın buluyordu; bir kaideye tebaiyet edercesine odasına gelişleri vardı ki Behlül'de fena bir tesir bile uyandırıyordu; (...) Behlül, pek sarih olmamakla beraber, bu kadının elinde kendisinin, asıl kendisinin bir kadın hükmünde kalmağa başladığını fark eder oluyordu. Odasında gelinip aranılan, her arzu olundukça alınıp tasarruf edilen kendisiydi. Pek iyi tahlil etmeksizin bu muaşaka tarzından kendisine bir zillet çıkarıyor ve kalbinin ta derin, kendi nefsine karşı bile hafî tutulan bir noktasında Bihter'e bir husumet his ediyordu ${ }^{63}$.

Burada Bihter'in ve Behlül'ün bedenleri, kültürün kodlandığı birer levha olarak karşımızdadır. Yukarıda da bedenin temsili üzerinden bir episteme değişimi söz konusudur. Behlül'ün zilleti ve Bihter'e hissettiği husumetin altında yatan, Behlül'ün geleneksel eril rolünden arınması ve bu rol değişiminin onun üzerinde yarattığı travmadır. Burada Bihter'in Behlül'e karşı duyduğu hissin bir tür hınç olduğunu, Bihter'in Behlül'e adeta hınçlandığını söylemek mümkün hâle gelir. Bu Max Scheler'in "Ressentiment” olarak çizdiği duyguya çok yakındır ${ }^{64}$. Behlül, Intibah ve Araba Sevdası'nda kandırılan erkek rolünü de aşarak, kendisini efemineleştirilmiş hisseden bir karakter olarak karşımıza çıkar. Behlül, kullanıldığını hissetmekte, bu “muaşaka tarzından kendisine bir zillet" çıkarmaktadır.

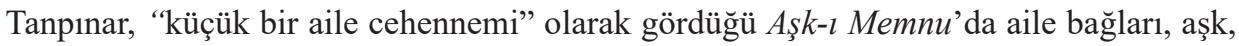
iradesizlik ve günahın, romanın bütün karakterlerini birbirine bağladığı görüşündedir. Ona göre “Aşk-ı Memnu' da vaka çok çabuk gelişir. Bu belki de kahramanların günahlarının yükünü taşıyamayacak kadar zayıf olmalarındandır"65. Aşk-ı Memnu'nun "en çarpıcı bölümlerinden biri, Bihter'in yarı karanlık odada aynanın karşısında çıplak vücudunu seyrettiği sahnedir" ${ }^{\prime 6}$.

62 Daryush Shayegan, Yaralı Bilinç: Geleneksel Toplumlarda Kültürel Şizofreni, çev. Haldun Bayrı (İstanbul: Metis Yayınlar1, 2007), 63.

63 Uşaklıgil, Aşk-ı Memnu, 227.

64 Max Scheler, Hınç: Ressentiment, çev. Abdullah Yılmaz (İstanbul: Kanat Kitap, 2004).

65 Ahmet Hamdi Tanpınar, Edebiyat Üzerine Makaleler (İstanbul: Dergâh Yayınları, 2014), 285.

66 Nurdan Gürbilek, Kör Ayna Kayıp Şark: Edebiyat ve Endişe (İstanbul: Metis Yayınları, 2007), 144. 
Birden bu yarı karanlık odanın içinde, evin uyuyan sükûnunun arasında, başının üstünden fenerin mülevven camlarından renk renk gölgeler yağarak bütün etrafında eşyayı sanki his edilmez bir rüzgârla canlandırırken kendisini böyle çıplak bulmaktan titredi, bu yalnızlıktan korktu. Hayır, bu öyle bir his idi ki, korkudan ziyade utanmağa yakın idi. Utandı, büyük bir ayıp yapmış, ismetine karşı düşünmeksizin bir günah işlemiş olmaktan utanıyordu; odasının mahremiyetine gizlice hulûl etmiş, meçhul bir sevdakârın kolları arasına düşüvermiş, mukavemet olunamıyan bir asab lerzişi içinde ilk aşk günahı vücuda gelmiş kıyas ediyordu ${ }^{67}$.

Bihter bedeni üzerinden bir utanma ve suçluluk hissiyle doludur. "Suçluluk, bir sinıra (üstbenin koyduğu) dokunulduğunda ya da bu sınır ihlâl edildiğinde ortaya çıkarken utanç bir amaca (ben idealinin koyduğu) ulaşılamadığı zaman kendini gösterir. Utanç başarısızlığa eşlik eder, suçluluk ise ihlâle" ${ }^{68}$. Bihter'in hissiyatı utançla suçluluğu iç içe geçmiş bir hâlde deneyimliyor olmasıdır. Bütün bunlar da Halit Ziya'nın romanlarının Tanzimat'tan farklı bir epistemolojik zemin üzerinde ilerlediğini göstermektedir.

Aşk-ı Meтnu, belki de her şeyden önce bir trajedinin romanıdır. Tanpınar, "Edebiyat-1 Cedide'nin kültür meselesi karşısındaki davranışı, sonunda bütün hareketin intiharına benzeyen Aşk-ı Memnu' da toplanmıştır” diyerek, romanın hem bir kültür meselesini sorunsallaştırdığını vurgular hem de onun trajik yanına vurgu yapar ${ }^{69}$. Aslında romanın geneline yayılan trajedi duygusu, metnin daha ilk satırlarından itibaren varlığını hissettirir. "Romanın ilk sahnesinde de Bihter'in yüzü ve bu yüzdeki ağırbaşlı ifade tasvir edilmiştir. Firdevs Hanım, belirsizlik veren bakışlara sahipken Bihter, 'vakar' ve 'endişe' ile bakmaktadır. Bu tasvir Bihter'in sürükleneceği trajediyi sezdirmekte, Firdevs Hanım'ın toplumsal kabulleri hiçe sayan yapısının yanında Bihter, yüzünün hemen her ayrıntısıyla annesinden farklı kabullere sahip olduğunu göstermektedir"70. Bihter'in aynanın karşısında bedenini tüm çıplaklığıyla duyumsaması da yeni bir trajedinin habercisidir. Bu türden bir trajedinin eski kültürde yeri yoktur. Tanpınar'ın aktardığına göre Massignon İslam sanatlarında trajedinin var olmadığı görüşündedir. Çünkü İslam'ın kabul ettiği tek varlık Allah'tır ve bu nedenle yaşam da bir gölge oyunundan ibarettir ${ }^{71}$. Yeni romanın temsilcisi konumundaki Aşk-ı Memnu' da ise her şeyden önce insanın trajedisini kurgulanır. Eski insanın adanmışlıkları, yeni insanın trajedileri vardır. Yeni insan, bedenini bir varlık gibi duyumsayıp vahdet-i vücut düşüncesinden ayrıldıkça kendisini bir trajedinin kucağında bulacaktır artık. Bu trajedi Bihter'le sınırlı değildir; trajedi bir neslin, bir dönemin trajedisidir artık. Ahmet Cemil'in yaşadığı hayal kırıklıkları, Raci'nin perişanlığı ve Bihter'in kendisini intihara sürükleyecek boyuta varan yıkımı hep bu trajedinin görünümleridir. Bilginin (episteme) şarkî bellekteki dönüşümü, karşımıza yüz ve beden üzerinden yeniden inşa edilen

67 Uşaklıgil, Aşk-ı Мemnu, 141.

68 Chasseguet-Smirgel, Janine, Ben İdeali: İdeal Hastalı̆̆ Üzerine Bir Psikanaliz Denemesi, Fransızca'dan çev. Nesrin Tuna (İstanbul: Metis Yayınları, 2005).

69 Tanpinar, Yahya Kemal, 86.

70 Ferda Atll, Aşk-ı Memnu Roman Kişilerinde Beden-Ruh İlişkisi: Anasır-ı Erbaa'dan Ahlat-ı Erbaa' ya Kretschmer, Sheldon ve Corman'dan Freud (İnönü Üniversitesi Sosyal Bilimler Enstitüsü Doktora Tezi, 2017), 127.

71 Tanpınar, XIX. Asır Türk Edebiyatı Tarihi, 24. 
bir kurgusal dünya çıkarmaktadır. Romanın varlığının neredeyse a priorisi olan çatışma unsuru bütün yönleriyle artık Türk romanında da yerini almıştır.

\title{
8. İpi Kopmuş Tesbih: Peyami Safa'da Ontolojik Kopuş
}

Türk romanı, Türk kültürünün Batı-dışı bir modernleşme dizgesinde ilerlediğini gösteren metin örnekleriyle doludur. "Bizim modernimiz bize göredir" görüşünü taşıyan Peyami Safa'nın romanları varlık sorunsalının karakterlerin yüz ve beden biçimlerine kodlandığı metinlerdir ${ }^{72}$. Safa'nın fizyonomiyle olan ilgisi hem kişisel hem de entelektüel düzeydedir. Safa, Londra' dan Paris'e yaptığı bir tren seyahatindeki gözlemlerini bir yazısında şöyle paylaşır: "Sıcak, alınlarımızı 1slatıyor ve boğazımızı kurutuyordu. Vagonrestorana geçtik. İlk defa bir Fransız garsonuna rahatça bakabildim ve Balzac’tan Carco'ya kadar okuduğum Fransız romanlarındaki tiplerden birini bu garsonun yuvarlak ve etli yanaklarında, birkaç teli kaşının üstüne düşmüş seyrek sarı saçlarında, kalın boynunda, geniş ve çok yuvarlak omuzlarında, hiçbir nokta üstünde durmayan hareketli ve sinirli bakışlarında, masamıza hala gelmeyerek mutfakla salon arasında sebepsiz görünen dolaşışlarında aradı"73. Anlaşılan Safa insanları bir fizyonomist dikkati ile gözlemlemektedir. Döneminin fizyonomistlerinden Ernst Kretschmer'i okumuş olan Safa, karakteroloji denilen huy bilgisinden hareketle insan vücudunu "manasına sımsıkı bağlı bir ifade" olarak görür74. Kaybolan Adam'da Şerlok Holmes fizyonomi ilmine inandığı için, tanıştığı polis müdürü ve Mehmet Rıza'nın “çok zeki ve iyi idareci olduklarını” anlar ${ }^{75}$. Onun karakterlerinin fizyonomisi de, Türk modernleşmesinin Batı-dışı bir ontolojik dizgede ilerlediğinin göstergesidir.

Safa'nın karakterlerinde yüz ve bedenin görünümleri Türk modernleşmesinin kendine özgü karakterini verecek biçimde gerçekleşir ve ontolojik kopuşun simgesel alanına dönüşür. Karakterlerin fizyonomisi bizi Shayegan'ın ontolojik kopuş kavramına götürür. Shayegan'a göre tasarladığımız şeylerin karşımızdaki şeylere göre geç kalmış olması, kronolojik bir uyumsuzluk değil, ontolojik bir bölünmedir:

\begin{abstract}
Düşüncem, tarihteki büyük sarsıntıların uzağında kalmıştır. Batı' da teknik-bilimsel altüst oluşların neden olduğu devrimler, bilinci her seferinde yeni bir bakışın gereklerine uyduran bir paradigma değişikliğine yol açmışken, benim durumumda böyle olmamıştır. Bilincim hâlâ büyülü dünyanın zamanında yaşamaktadır. Sürekli bir bombardıman sonucunda yeni şeylerde- ki engellenmez çekiciliğin etkisinde olduğum doğrudur, ama bunların şeceresi ve arkeolojisi benim için bilinmez olarak kalmaktadır ${ }^{76}$.
\end{abstract}

Safa bu ontolojik kopuşu Doğu ile Batı arasındaki karşılaştırma üzerinden verir. Nurdan Gürbilek'in Fatih-Harbiye'den hareketle sözünü ettiği “ikili karşıtlıklar semiyotiği ('iki zıt

72 Peyami Safa, Sanat Edebiyat Tenkit: Objektif: 2 (İstanbul: Ötüken Yayınları, 1976b), 207.

73 Peyami Safa, Büyük Avrupa Anketi (İstanbul: Kanaat Kitabevi, 1938), 34.

74 Peyami Safa, Eğitim Gençlik Üniversite (Objektif: 7) (İstanbul: Ötüken Yayınları, 1976a), 19.

75 Peyami Safa, Kaybolan Adam (İstanbul: Damla Yayınları, 1977), 12.

76 Shayegan, Yarall Bilinç, 14. 
iştiyakın remizleri')"’77, onun bir çok romanında geçerli bir izlek olarak karşımıza çıkar. Bu ikili karşıtlıklar semiyotiğinin derin yapısında hem Batı hem de Doğu düşüncesini uzun süredir meşgul eden ruh-beden ikiliği de yer alır. Peyami Safa’nın metinleri bu ikiliklerin bedenin temsili üzerinden verilmesi bakımından da oldukça dikkat çekicidir.

Yalnızız ve Matmazel Noraliya 'nın Koltuğu, yazarın "son dönem yapıtları"78 ve "en olgun eserleri" " olmalarının yanında, karakterlerin fizyonomisi ve bu fizyonominin varlık sorunsalının ele alınışı bakımından da dikkat çekici metinlerdir. Parla'ya göre "Türk romanı, camiacı bir kültür içinde beslenen idealist bir dünya görüşünün ve bilgi kuramının ürünü olarak doğ[muştu]". Buna göre 1870-90 yılları arasında yazılan Türk romanları "apriorist, idealist bilgi kuramına daha yakındı"80. Parla’ya göre "romanın çıktığı 1870'li yıllarda henüz hiç kimse bu epistemolojik karşıtlığın [Doğu-Batı karşıtlığının] bilincinde gibi görünmüyordu ve Beşir Fuat'a kadar Tanzimat düşünür ve yazarlarının tek bir ontolojik ya da metafizik soru sormamıştı" ". . Bu durum, özellikle Safa’nın romanlarıyla birlikte değişecektir.

Yalnızız'da Samim, bir fizyonomist tavır içinde resmedilir. Samim liseden beri, arkadaşlarının hâleti ruhiyelerini anlamak merakındadır. Bu merak Samim'de bir delilik hâlindedir: "Bahçeden sınıfa girdiğimiz zaman, yerlerine oturmak için yanımdan geçenlerin yüzlerine, dikkatimi sezdirmeden bakmak âdetimdi. Teneffüste, talebe grupları içinde susar ve söylenen sözlerden ziyade gizlenen temayülleri anlamaya çalışırdım" ${ }^{82}$. Samim'in arkadaşlarının hâleti ruhiyelerini anlama merakında oluşu ve söylenen sözlerden ziyade gizlenen eğilimleri anlamaya çalışması, modern bellek kuramını hatırlatır. Maurice Merlau-Ponty'nin fenomenolojisinin etkisiyle gelişen bellek kuramı, "başkalarının davranışlarını açıklamak ve tahmin edebilmek için geliştirdiğimiz bir tür zihin okuma sürecidir/yetisidir"\$3. Merleau-Ponty için başka insanlar asla saf ruh değildir: “Bakışları, davranışları, sözleri, yani kısacası vücutları aracılığıyla tanırım başkalarını (...) başkasını düşündüğümde anımsadığım şey, onun manevi portresini çizen şey, binbir türlü yönelimle kıpraşan ve bir çok eyleme ya da niyete hizmet eden vücududur" "84. Safa'nın Samim karakterini bir fizyonomist biçiminde geliştirmesi de tesadüf değil bilinçli bir tercihtir. Safa, dikkatli bir göz için, "her insan bedeninin bir kitap gibi taşıdığı manaları önümüze serdiği”" görüşündedir ${ }^{85}$. Bu manalar onun için o derece önemlidir ki, insanlar Simeranya’ya ancak bir fizyonomi ve tavır yoklaması ile girebilecektir:

Kılavuzuma baktım. Kadındı. Şaşırdım (...) İri gözleri dosdoğru ruha bakıyor. Gözlerim, zengin ifadeli ve küçük ağzının üstünde eski dünyamdan kalan arzuların verdiği dikkatle

77 Nurdan Gürbilek, Sessizin Payı (Denemeler) (İstanbul: Metis Yayınları, 2015), 85.

78 Berna Moran, Türk Romanına Eleştirel Bir Bakış-1(İstanbul: İletişim Yayınları, 1998), 128.

79 Mehmet Tekin, Romancı Yönüyle Peyami Safa (İstanbul: Ötüken Yayınları, 2014), 30.

80 Parla, Babalar ve Oğullar, 14.

81 Parla, Babalar ve Oğullar, 49-50.

82 Peyami Safa, Yalnızız (İstanbul: Ötüken Neşriyat, 1978), 122.

83 Shaun Gallagher, "Hermeneutics and the Cognitive Sciences", Journal of Consciousness Studies 11 (2004), 10.

84 Maurice Merleau-Ponty, Algılanan Dünya (Sohbetler) (İstanbul, Metis Yayınlar1, 2008), 48.

85 Safa, Ĕgitim Gençlik Üniversite, 19. 
dururken, devamlı bir şimşek aydınlığına benzeyen keskin bir 1şık beni sıçrattı. İskeleye doğru baktım. Yelkenli durmuştu. Kılavuzum nefes halinde bir sesle bana ihtar etti:

- Dikkat ediniz. Fizyonomi ve tavır yoklamanız yapılıyor. İçinizi okuyorlar.

Eski dünya hislerinizden kurtulunuz. Yoksa kabul edilmezsiniz ${ }^{86}$.

Simeranya' da neden fizyonomi ve tavır yoklaması yapılmaktadır? Dahası anlatıcının eski dünyasından kalan ve kurtulması gereken hisler ne anlama gelmektedir? Yazar, eski dünya derken nereyi kastettiğini, “Simeranya’ya göre bugünkü dünyamız” diyerek açıkça işaret edecektir. Sözünü ettiği eski dünya ilminin en büyük hatalarından biri, “ihtisas bölümlerine ayrılan ilimlerin 'bütün 'ü gözden kaçırdıkları için hiçbir hadiseyi esaslı ve doğru izah edemediklerini anlamamış olmaları[dır]" ${ }^{\prime 87}$. Bu da, parçanın karşısında bütünü koyma arzusundaki yeni bir ontolojinin habercisidir. Safa'nın karakterlerini özgün kılan, onların fizyonomilerinin simgeleştirdiği bu yeni ontolojinin Batı tarafından bütünüyle deneyimlenmemiş, şarklıya has bir çizgiden geliyor oluşudur. Roman ilerledikçe, yazar ruhumuza ait sırları karakterlerinin vücutlarının vitrininde bir bir teşhir eder:

Gözleri, gözleri... onu doğduğu günden evvelki benliğime sımsıkı bağlayan, en yakın akrabadan daha yakın bir kan münasebetini kat kat aşan ve ruhlarımızın beraberliği hissini bir anda uyandıran bakışlarında kendimi ne kadar çok buluyorum. Sanki onun gözleriyle kendimi gören ben'im. Onun varlığını benimkinin şartı haline getiren bu ayrılık duygusunda, görme intibalarl tek merkezde birleşen iki gözün beraberliğine benzeyen bir fonksiyon birliği var ${ }^{88}$.

Yazar, varlık sorunsalına yaklaşımını birleşen iki göz arasındaki fonksiyon birliği düşüncesi üzerinden vermektedir. Göz, yüzün ruha açılan penceresidir ve bu yönüyle yine simgesel bir alana dönüşür. Bilindiği gibi, "Simeranya, olayların geçtiği zamandan yaklaşık yüzelli yıl sonra yaşanacak ve bizim dünyamızın bütün problemlerini halletmiş insanların bir araya geldiği bir dünyadır"89. Simeranya'nın başlıca özelliği, Samim’in "olmak dramı” adını verdiği dip zıtlı̆̆ın, varlı̆̆ın temellerini sarsan büyük ıstıraplarından" kurtulmanın reçetesini sunuyor olmasıdır ${ }^{90}$. Bu reçetenin nihaî amacı, bir kadının gözlerinde ruhlarının beraberliğini bulan, onun gözleriyle kendisini gören, hatta onun varlığını kendi varlığının şartı haline getiren Samim'in tavrında gizlidir. Bu "bir ruh hamlesi ve hareket halinde bir ebedîlik prensibidir". Gözler arasındaki bağ güçlüdür ki, bir öznenin varlığı, gözler üzerinden, bir diğerinin varlığının şartı hâline gelir. $\mathrm{Bu}$, Türk romanında Batı romanındakinden farklı bir özneler arasılık perspektifi olduğunu gösterir. Foucault'nun Batı ile Doğu-İslam kültürlerini ayırırken kullandığı hümanizma sözcüğü “bireysellik" olarak yorumlandığında Foucault'nun yorumu bu noktada bir kez daha devreye girer.

86 Safa, Yalnızız, 25

87 Safa, Yalnızız, 50

88 Safa, Yalnızız, 45.

89 Mehmet Önal, Peyami Safa'nın Romanlarında Fiktif Yapı (Selçuk Üniversitesi Sosyal Bilimler Enstitüsü Doktora Tezi, 1989), 426.

90 Safa, Yalnızız, 134. 
Safa'nın modern mistisizmin öncülerinden Emile Boutrouz'nun vecde dair sözlerini, incelemesinin en güzel izahlarından biri olarak kabul etmesi boşuna değildir. Boutrouz vecdi, ruhun hedefiyle birleşmesi olarak görür. Ona göre ruh ile beden arasında hiç bir vasıta yoktur ${ }^{91}$. Safa da varlığı, bu birleşmenin, bir olmanın penceresinden görmekte, varlığını kendi varlığının şartı haline getiren ayrılık duygusunda, görme duyusunun tek merkezde birleştiği bir fonksiyon birliği bulmaktadır.

Matmazel Noraliya'nın Koltuğu, Tanpınar'ın deyişiyle, Safa’nın “eski meselelerini ve hayat tecrübelerini daha spiritüel bir plana nakle[ttiği]" romanıdır"2. "Romanda, maddeci bir felsefeyle şekillenen ontik kaygıların giderilmesi, ruhsal tekâmüle ve bir takım mistik tecrübelere bağlanır"93. Burada bizi asıl ilgilendiren soru, romanda karakterlerin yüz ve beden biçimlerinin Türk modernleşmesi bağlamında nasıl bir simgesel alana işaret ediyor oluşudur. Romanın başlarında Ferit'in bitişik odasındaki kiracının yaşı belli olmayan kızından hareketle söylenenler oldukça dikkat çekicidir. Yangında sesi kaybolan, dili tutulan bu kız, kendisine söylenenleri “[a]nlar, fakat gık bile diyemez”. Ferit ilk gidişinde yüzünü göremediği bu kızın hayalini görecek ve yüzünü gördüğünde, biraz evvel zihninde beliren yüzle aynı olmasının şaşkınlığını yaşayacaktır: "Ferit, (...) şuurun sathına dışarıdan vuran, bir projeksiyon gibi değil, normal olduğu için korkutmayan bir tasavvur halinde kızın gözlerini hatırladı. Şimdi onları daha net görüyordu. Hiç şüphesiz bunlar, sesi çıkmayan sahibinin içinde boğulan manaları dışarıya nakletmek için, her gün biraz daha artan bir ifade kabiliyeti edinmeye çalışıyorlardı" "94. Bu kızın fizyonomisinden hareketle, artık konunun Bergson'a bağlanmasının vakti gelmiştir. Ferit, "Tıp Fakültesini bırakıp felsefeye devam ettiği günden beri, manalar yüklü bir ses perdesinin, bir iç çekişin, bir yüz kımıldatışının, bir bakışın bazan sayfalarca yazıya bedel ifade kıymetinde, nominal vetireleri aşan, daha zengin ve kökleri daha derin bir semboller sistemi olup olmadığını çok düşünmüştü[r]"95. Romancı fizyonomi bilgisine dayanan bu gözlemlerinin ardından, ruhun bedene yansımasını Bergson’un dureésine bağlayacaktır:

Belki ruhun mahrem ürperişlerinin kelimelerden ziyade sese, bakışlara ve tavırlara vurması, onlara, düre içinde, lügat manalarına sığmayacak kadar sayısız yorumlanma imkânları veren serbest uzanışlarının, bakış veya tavır gibi hareketli ifade vasıtalarında canlı manalarının şartı haline getiren kımıldanışı ve düreyi bulabilmelerindendi ${ }^{96}$.

Matmazel Noraliya'nın Koltuğu'nda karakter fizyonomisi bir kez daha simgesel bir alana dönüşür. Konuşamayan küçük kızdan Ferit'in hayaline, oradan da Bergson'a giden puzzle'1

91 Peyami Safa, Mistisizm (Büyük Fikir Cereyanları: 2) (İstanbul: Bâbıâli Yayınları, 1961), 10.

92 Tanpınar, Edebiyat Üzerine Makaleler, 124.

93 Beyhan Kanter, Kurmaca Bedenler: Türk Romanında Bir Söylem Biçimi Olarak Beden (1923-1980) (İstanbul: Kesit Yayınları, 2019), 122.

94 Peyami Safa, Matmazel Noraliya ’nın Koltuğu (İstanbul: Nebioğlu Yayınları, 1949), 18.

95 Safa, Matmazel Noraliya'nın Koltuğu, 18-19.

96 Safa, Matmazel Noraliya'nın Koltuğu, 19. 
çözmek ancak fizyonominin anlaşılmasıyla mümkündür. Küçük kız üzerinden verilen "bir yüz kımıldatışının, bir bakışın bazan sayfalarca yazıya bedel ifade kıymeti” Bergson’un “dureé”sindeki şifreleri çözmemizi sağlar. Bergson üzerinden verilen “yaşama hamlesi” ya da “varlaşma”ya dair düşünceleri hatırlandığında, yazarın zaman olgusuna yaklaşımının tesadüf değil, bir tercih olduğu kendiliğinden anlaşılır.

Bu gözlerden bakışla beraber çıkan, fakat manadan bambaşka bir şey, maddi ve manevi hiçbir şeyle izahı mümkün olmayan Ferit'in bütün varlığını sarıyordu. Zehra'nın gözlerinde olduğu gibi bu, boğulmuş heyecanların bakışlar yoluyla taşması değildi. Burada, bilâkis, burada, insanı sardıktan sonra içeriye çeken ve ruhun ötelerine, her şeyin ötesine götüren, ebedîlikte tasarladığımız hareketsizliğe, maddesizliğe ve manasızlığa yakın fakat hazdan bayıltacak kadar tatlı ve derin bir hal vardı (...) Bulundu Selma, bulundu. Ne? Edebîlik. Bu, benim gözlerimin altında senin bakışındır ${ }^{97}$.

Matmazel Noraliya'nın Koltuğu'nda fizyonomi üzerinden yapılacak bir yakın okuma, bir yandan romanın derin anlamının ortaya çıkarılmasına katkı sunarken, varlık sorunsalının ele alınma biçimlerindeki özgül yönleri ortaya koymaktadır. Her şeyden önce roman karakterleri bir Şarklının varlık sorunsalına yaklaşımını birbirlerinin yüz ve beden biçimleri üzerinden yansıtırlar. Bu bir yönüyle kırılmış cam parçacıklarının ya da bir odadaki aynaların birbirini yansıtmasına benzer. Ferit, Selma’nın eksik kalan ruh yönünü temsil ederken, Yahya ve bir yönüyle Matmazel Noraliya, Ferit'in mistik yolculuğuna 1şık tutacaktır. Safa, "romanda geleneksel romanın anlatım tekniğinden uzaklaşarak modern roman tekniğini, yani gösterme yolunu seç[er]" dikkati çeken romancının "gösterme" işlemi sırasında karakterlerin fizyonomisinden ustaca yararlanmış olmasıdır. Örneğin Noraliya’nın metafizik yolculuğu, Aziz’le Ferit arasındaki konuşmada Noraliya'nın resmi üzerinden verilir. Burada dikkat çekici olan Peyami Safa'nın mistik modernizmini dönemin en ünlü fizyonomistlerinden Corman üzerinden veriyor oluşudur:

\begin{abstract}
Resimde yüzüne dikkat ettiniz mi? Alından ve gözlerden sonra bütün parçalar ufalıyor. Evet, bu vücut, 15 yaşında bir kız çocuğuna ait gibidir. Bütün enerji kafatasının üst kısmına yükselmiş, orasını geliştirmiş ve geri kalan bütün organları nemasız bırakmış. Morfopsikolojide, hiç şüphesiz, corman haklıdır.burada da şiddetli bir hypperexcitabilite eşliğinde catabolism'e çıkan garip bir intibak, daha doğrusu intibaksızlık görüyoruz. Yani uzviyet, muhtevası olan ruh gibi, içinde bulunduğu cevreye, intibak edemediği için geriye çekilmiş, büzülmüş, kurumuş bir haldedir ${ }^{99}$.
\end{abstract}

Ferit'in iç yolculuğu, varlığın birincil aşamalarından biri olan ruh-beden sorunsalının çözümünde bir atlama tahtasıdır. Birazdan Ferit, mistik tecrübenin dahilinde bir vecd hali yaşayacak, bu da onun aydınlanmasında birinci dereceden rol oynayacaktır:

97 Safa, Matmazel Noraliya'nın Koltuğu, 120.

98 Moran, Türk Romanına Eleştirel Bir Bakış-1, 143.

99 Safa, Matmazel Noraliya'nın Koltuğu, 260. 
Ferit gözlerini kapadı. Kendini bıraktı, yerini tayin edemediği, hatta ona vücuduna olduğu kadar ruhuna da bağlı çözülüşler duyuyordu. Şimdi, içinde ne olduğunu bilmediği, varlığının cevherini andıran ve günlerden beri dügümlene düğümlene kasılan bir şey, beyninden avuçlarına ve tabanlarına uzanıyor, vücudundan dışarı çıkacakmış gibi buharlanarak yayılıyordu ${ }^{100}$.

Bu kelimenin tam anlamıyla mistik tecrübenin esası olan "vecd" durumudur. Yazarının Mistisizm 'de vecd/extase'ye dair verdiği, “[r]uh, kendisinin ötesine, bilinmez bir bölgeye vardığını sanır (...) tecrit hali, ruhun transandan (yüceltilmiş) bir gerçeği kavramasına yarar" biçimindeki bilgi, Ferit'in halini tam olarak açıklamaktadır ${ }^{101}$. Bütün bunlar, romancının, Ferit' in "vecd"ini okura duyurup romanın tezine ulaşırken bir kez daha fizyonomiyi bilinçli biçimde kullandığını gösterir. Ayrıca "Ferit, yaşadığı içsel değişimi ve aydınlanmayı, gözlerdeki aydınlanmayla ortaya koyar"102. Bu nedenle Moran'ın "belki başka hiçbir Türk romanında, yazar, okur üzerinde uyandırmak istediği etkileri bu kadar hesaplı bir şekilde ele almamıştır"103 biçimindeki tespiti son derece doğrudur.

\section{Sonuç}

Modernitenin Batı kaynaklı bir kültürel norm olarak kendisini göstermesi, Batının dışında kalan modernite deneyimlerinin de Batı üzerinden okunması sonucunu doğurmuştur. Oysa Batıdışı kültürler, kendilerine özgü tarihî şartlarından kaynaklanan bambaşka deneyimler yaşamış, bu deneyimler öncelikle sanatsal üretim biçimlerine yansımıştır. Birbirinden farklı formlar/ formatlar altında, çok köklü bir anlatma/tahkiye geleneğine sahip olan Türk edebiyatı, Tanzimat ile başlayan süreçte, roman türünün ilk örneklerini vermiş, bu dönemde yazılan eserlerde romancilar, geleneksel bir epistemolojinin ürünü olan mutlakçı bir kurgu ile metinlerini kaleme almışlardır.

En eski dönemlerden bu yana araştırmacıların ilgisini çeken insanın yüz ve beden biçimleri, Doğu'da ilm-i sima ve ilm-i feraset; Batı'da ise fizyonomi ve frenoloji gibi çalışma alanlarının doğmasını sağlamıştır. Bu çalışmaların ortak yönü, insanın bedensel varlığ 1 ile iç dünyası arasındaki ilişkiye odaklanıyor olmalarıdır. Batı'da modern roman üzerinde tizi çalışmalar yapılmış olmasına ve Batı romanında karakterlerin fizyonomileri üzerinden derinlikli araştırmalar gerçekleştirilmiş olmasına rağmen, Türk romanında karakter fizyonomisi yeterince irdelenmemiş, kurgusal karakterin yüz ve beden biçimlerinin kültürel çağrışım alanları akademik bir boyutta kapsamlı olarak ele alınmamıştır. Oysa Türk romanında karakter fizyonomisi, romanımızın nasıl bir epistemoloji ve ontolojiye sahip olduğunu ve bu alanlardaki değişiminin izlenebilmesi açısından büyük önem taşımaktadır.

"Kurgusal Fizyonominin Şarkî Aynaları", romancılarımızın Türk modernleşmesine has karakterler kurguladığı tezi üzerine kurulmuş bir nitelendirmedir. Bu çerçevede çalışmada

100 Safa, Matmazel Noraliya'nın Koltuğu, 182.

101 Safa, Mistisizm, 17.

102 Emel Aydın Özer, "Bedenin Roman Hâli: Matmazel Noraliya’nın Koltuğu’nda Beden ve Kişilik” Hece 217 (2015), 322.

103 Moran, Türk Romanına Eleștirel Bir Bakış-1, 144. 
yakın okuma yöntemi ile karakterlerin yüz ve beden biçimleri incelenmiş, onların yüz ve bedenlerinin kültürel bir simge alanına karşılık geldiği anlaşılmıştır. Araştırma objesi olarak seçilen Mai ve Siyah ve Aşk-ı Memnu'da bilgi sorunsalının romandaki görünümleri açısından incelenmiş, karakterlerin Tanzimat'ın geleneksel dünya görüşünden ayrılarak, daha modern bir dünya görüşüne doğru evirildiği anlaşılmıştır. Sözü edilen iki metin, Foucault'nun tarihsel a priori ve arşiv olarak adlandırılan görüşlerinden hareketle yorumlandığında, Halit Ziya'nın içinde bulunduğu ve adına modernleşme denilen kültürel değişimin bazı dikkat çekici yönlerini yansıttığı ve bunu, "insiyaki” biçimde karakterlerin yüz ve beden biçimine yansıttığı anlaşılmıştır. Böylece, Tanzimat'ın ardından romanımızın epistemolojik bakımdan hangi yönde ilerlediği ve Halit Ziya'nın romanlarının Türk edebiyatının batılı anlamda ilk olgun örnekleri olarak kabul edilmesi gerekliliği daha açık biçimde anlaşılmıştır.

Peyami Safa’nın romanları, Türk modernleşmesinin Batı-dışı modernite olarak temellendirilmesini sağlayan karakter fizyonomileri sunmaktadır. Çalışmamız sırasında gerçekleştirdiğimiz yakın okumalar, Safa'nın varlık sorunsalını irdelerken, bunu, karakterlerinin fizyonomileri üzerinden gerçekleştirdiğini göstermiştir. Shayegan'1n ontolojik kopuş kavramı üzerinden okunduğunda Yalnızız'da karakterlerin, varlıklarını anlamlı hâle getirmek için Simeranya'yı bu kopuşun ilacı olarak gördüklerini göstermiştir. Safa'nın kurgusal belleği, Samim merkezinde yapılan karakter okuması ile varlıklarını ancak bir birlikten hareketle anlamlandırabileceklerini düşünmektedirler. Safa'nın kurgusal bakımdan en olgun metinlerinin başında gelen Matmazel Noraliya 'nın Koltuğu, yazarının son derece bilinçli tercihleri sonucu hem karakter fizyonomisinin çağrışım alanlarına hem de ontolojik okumaya en çok imkân veren romanı olma hüviyetindedir.

Hakem Değerlendirmesi: Dış bağımsız.

Çıkar Çatışması: Yazar çıkar çatışması bildirmemiştir.

Finansal Destek: Yazar bu çalışma için finansal destek almadığını beyan etmiştir.

Peer-review: Externally peer-reviewed.

Conflict of Interest: The author has no conflict of interest to declare.

Grant Support: The author declared that this study has received no financial support.

\section{Kaynaklar/References}

Aristotle. Minor Works. Çeviren W. S. Hett. London. Cambridge: Harvard University Press, 1936.

Atlı, Ferda. Aşk-ı Memnu Roman Kişilerinde Beden-Ruh İlişkisi: Anasır-ı Erbaa'dan Ahlat-ı Erbaa'ya Kretschmer, Sheldon ve Corman'dan Freud'a. İnönü Üniversitesi Sosyal Bilimler Enstitüsü Doktora Tezi, 2017.

Aydın Özer, Emel. “Bedenin Roman Hâli: Matmazel Noraliya’nın Koltuğu’nda Beden ve Kişilik”, Hece 217 (2015): 320-331.

Banarlı, Nihat Sami. Resimli Türk Edebiyatı Tarihi. İstanbul: M.E.B. Basımevi, 1971. 
Baumbach, Sibylle. Shakespeare and the Art of Physiognomy. Penrith: Humanities Ebooks, 2008.

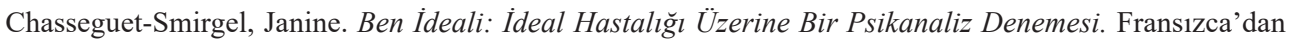
Çeviren Nesrin Tuna. İstanbul: Metis Yayınları, 2005.

Corbin, Alain, Jean-Jacques Courtine, Georges Vigarello. Bedenin Tarihi-1: Rönesans 'tan Aydınlanma'ya. Çeviren Saadet Özen. İstanbul: YKY, 2008.

Çonoğlu, Salim. "Servet-i Fünûn Romanında Beden Yapısı, Bedensel Davranışlar ve Kişilik İlişkileri Üzerine Bir Çözümleme”, Yeni Türk Edebiyatı Araştırmaları 1 (2009): 57-73.

Erzurumlu İbrahim Hakkı. Marifetnâme. Yayına Hazırlayan Cafer Durmuş. İstanbul: Erkam Yayınları, 2011. Foucault, Michel. Bilginin Arkeolojisi. Çeviren Veli Urhan. İstanbul: Ayrıntı Yayınları, 2019.

Fukuyama, Françis. The End of History and The Last Man. New York: The Free Press, 1992.

Gallagher, Shaun. "Hermeneutics and the Cognitive Sciences". Journal of Consciousness Studies 11 (2004): 1-15. Giddens, Anthony. Modernliğin Sonuçları. Çeviren Ersin Kuşdil. İstanbul: Ayrıntı Yayınları, 2004.

Göle, Nilüfer. "Batı Dışı Modernlik: Kavram Üzerine”, Modern Türkiye’de Siyasî Düşünce içinde, 56-67. Editörler Tanıl Bora, Murat Gültekingil. İstanbul: İletişim Yayınları, 2002.

Gürbilek, Nurdan. Kör Ayna Kayıp Şark: Edebiyat ve Endişe. İstanbul: Metis Yayınları, 2007.

----. Sessizin Payı (Denemeler). İstanbul: Metis Yayınları, 2015.

Hall, Stuart. Representation: Cultural Representations and Signifying Practices. London: Sage, 2003.

Hogarth, William. The Analysis of Beauty. London: W. Strahan, 1753.

Jay, Martin. Downcast Eyes: The Denigration of Vision in Twentieth-Century French Thought. Berkeley and Los Angeles: University of California Press, 1994.

Johnson, Mark. The Body in the Mind: The Bodily Basis of Meaning, Imagination, and Reason. Chicago and London: The University of Chicago Press, 1987.

Kanter, Beyhan. Kurmaca Bedenler: Türk Romanında Bir Söylem Biçimi Olarak Beden (1923-1980). İstanbul: Kesit Yayınları, 2019.

Kaderli, Zehra. "Kültürel Söylemlerin Biçimlendirme Yerlemi Olarak Beden ve Çağdaş Beden Modifikasyonlarının Fenomenolojik Boyutlar1", folklor/edebiyat 94/2 (2018): 161-182.

Kaplan, Mehmet. "Mâi ve Siyah Romanının Üslubu Hakkında", Ístanbul Üniversitesi Edebiyat Fakültesi Türk Dili ve Edebiyatı Dergisi XIX (1971): 51-72.

Kemal, Namık. Intibah: Sergüzeşt-i Ali Bey. Tertipleyen Mustafa Nihat Özön. İstanbul: Remzi Kitabevi, 1961.

Koçak, Orhan. "Kaptırılmış İdeal: Mai ve Siyah Üzerine Psikanalitik Bir Deneme”. Toplum ve Bilim 70 (1996): 94-152.

Kretschmer, Ernst. Beden Yapısı ve Karakter: Konstitüsyon Meselesi ve Mizaçlar Bilgisi Hakkında Araştırmalar. Çeviren Mümtaz Turhan. İstanbul: İÜ Edebiyat Fakültesi Yayınları, 1949.

Lakoff, George, Mark Johnson, Metaphors we live by. Chicago and London: The University of Chicago Press, 1987.

----. Philosophy in the flesh: The embodied mind and its challenge to Western thought. New York: Basic Books, 1999.

Lavater, Johan K. Essays on Physiognomy. Fransızca'dan Çeviren Henry Hunter. London: John Murray, 1792.

Le Breton, David. Yüz Üzerine Antropolojik Bir Deneme. Çeviren Oruç Türkay. İstanbul: Boğaziçi Üniversitesi Yayınlar1, 2008. 
Lukács, Georg. Writer \& Critic and Other Essays. New York: The Universal Library, 1971.

Lüleci, Murat. Gülün Tam Ortası: Bilişsel Yazınbilim ve İkinci Yeni’nin Bilişsel Temelleri. Ankara: Grafiker Yayınlar1, 2019.

Manguel, Alberto. Okumanın Tarihi. Çeviren Füsun Elioğlu. İstanbul: Yapı Kredi Yayınları, 2013.

Mardin, Şerif. Türkiye'de Toplum ve Siyaset. M. Türköne-T. Önder. İstanbul: İletişim Yayınları, 1990.

----. Türk Modernleşmesi. İstanbul: İletişim Yayınları, 1991.

Marx, Karl. Capital: A Critique of Political Economy. New York: Random House, 1906.

Merleau-Ponty, Maurice. Algılanan Dünya (Sohbetler). İstanbul, Metis Yayınları, 2008.

Moran, Berna. Türk Romanına Eleştirel Bir Bakış-1. İstanbul: İletişim Yayınları, 1998.

Narlı, Mehmet. “Tanzimat Romanında Beden ve Kişilik İlişkileri Üzerine Bir Çözümleme”, Yeni Türk Edebiyatı Araştırmaları 1 (Ocak-Haziran) (2009): 165-177.

Nietzsche, Friedrich. Tragedyanın Doğuşu. Çeviren İsmet Z. Eyüboğlu. İstanbul: Ataç Kitabevi, 1965.

Önal, Mehmet. Peyami Safa'nın Romanlarında Fiktif Yapı. Selçuk Üniversitesi Sosyal Bilimler Enstitüsü Doktora Tezi, 1989.

Parla, Jale. Babalar ve Oğullar: Tanzimat Romanının Epistemolojik Temelleri. İstanbul: İletişim Yayınları, 2008.

Robbet-Grillet, Alain. Yeni Roman. Çeviren Asım Bezirci. İstanbul: Yazko, 1981.

Safa, Peyami. Büyük Avrupa Anketi. İstanbul: Kanaat Kitabevi, 1938.

----. Matmazel Noraliya'nın Koltuğu. İstanbul: Nebioğlu Yayınları, 1949.

----. Mistisizm (Büyük Fikir Cereyanları: 2). İstanbul: Bâbıâli Yayınları, 1961.

----. Ĕgitim Gençlik Üniversite (Objektif: 7). İstanbul: Ötüken Yayınları, 1976a.

----. Sanat Edebiyat Tenkit (Objektif: 2). İstanbul: Ötüken Yayınları, 1976b.

----. Kaybolan Adam. İstanbul: Damla Yayınları, 1977.

----. Yalnızız. İstanbul: Ötüken Neşriyat, 1978.

Sayın, Zeynep. 'Batı'da ve Doğu'da Bedenin Temsilinde Haysiyet ve Zillet II: İslami Beden Temsili: İffet ve Zillet”, Defter 40 (2000): 193-234.

Scheler, Max. Hınç/Ressentiment. Çeviren Abdullah Yılmaz. İstanbul: Kanat Kitap, 2004.

Shayegan, Daryush. Yaralı Bilinç: Geleneksel Toplumlarda Kültürel Şizofreni. Çeviren Haldun Bayrı. İstanbul: Metis Yayınlar1, 2007.

Spolsky, Ellen. The Work of Fiction: Cognition, Culture, and Complexity. London: Ashgate, 2004.

Tanpınar, Ahmet Hamdi. Yahya Kemal. İstanbul: Dergâh Yayınları, 1995.

----. XIX. Asır Türk Edebiyatı Tarihi. İstanbul: Çağlayan Kitabevi, 1988.

---- Edebiyat Üzerine Makaleler. İstanbul: Dergâh Yayınları, 2014.

Taylor, Charles. "Two Theories of Modernity”, The Hastings Center Report 25/2 (1995): 24-33.

Tekin, Mehmet. Romancı Yönüyle Peyami Safa. İstanbul: Ötüken Yayınları, 2014.

Tylor, Edward B. Primitive Culture (Part I). London: John Murray, 1871.

Tytler, Graeme. Physiognomy in the European Novel: Faces and Fortunes. Princeton: Princeton University Press, 1982. 
Uşaklıgil, Halid Ziya. Aşk-ı Memnu. Naşiri İbrahim Hilmi. İstanbul: Hilmi Kitabevi, 1945.

----. Mai ve Siyah. İstanbul: İnkılap ve Aka Kitabevleri, 1968.

----. Hikâye (İnceleme). Hazırlayan Nur Gürani Arslan. İstanbul: YKY, 1998.

----. Ruhun Lisanı: İlm-i Sima. İstanbul: Büyüyenay Yayınları, 1894/2016.

Yücel, Tahsin. İnsanlık Güldürüsü’nde Yüzler ve Bildiriler. İstanbul: YKY, 1997.

Zunshine, Lisa. "Theory of Mind and Fictions of Embodied Transparency", Narrative 16/1 (2008): 65-92. 
